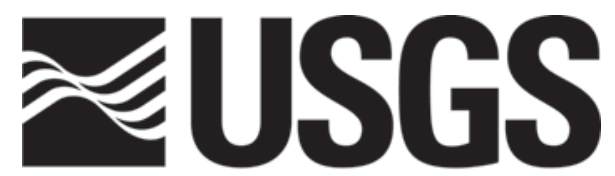

science for a changing world

Prepared in cooperation with the National Park Service

\title{
Assessment of Possible Sources of Microbiological Contamination in the Water Column and Streambed Sediment of the Jacks Fork, Ozark National Scenic Riverways, Missouri-Phase III
}

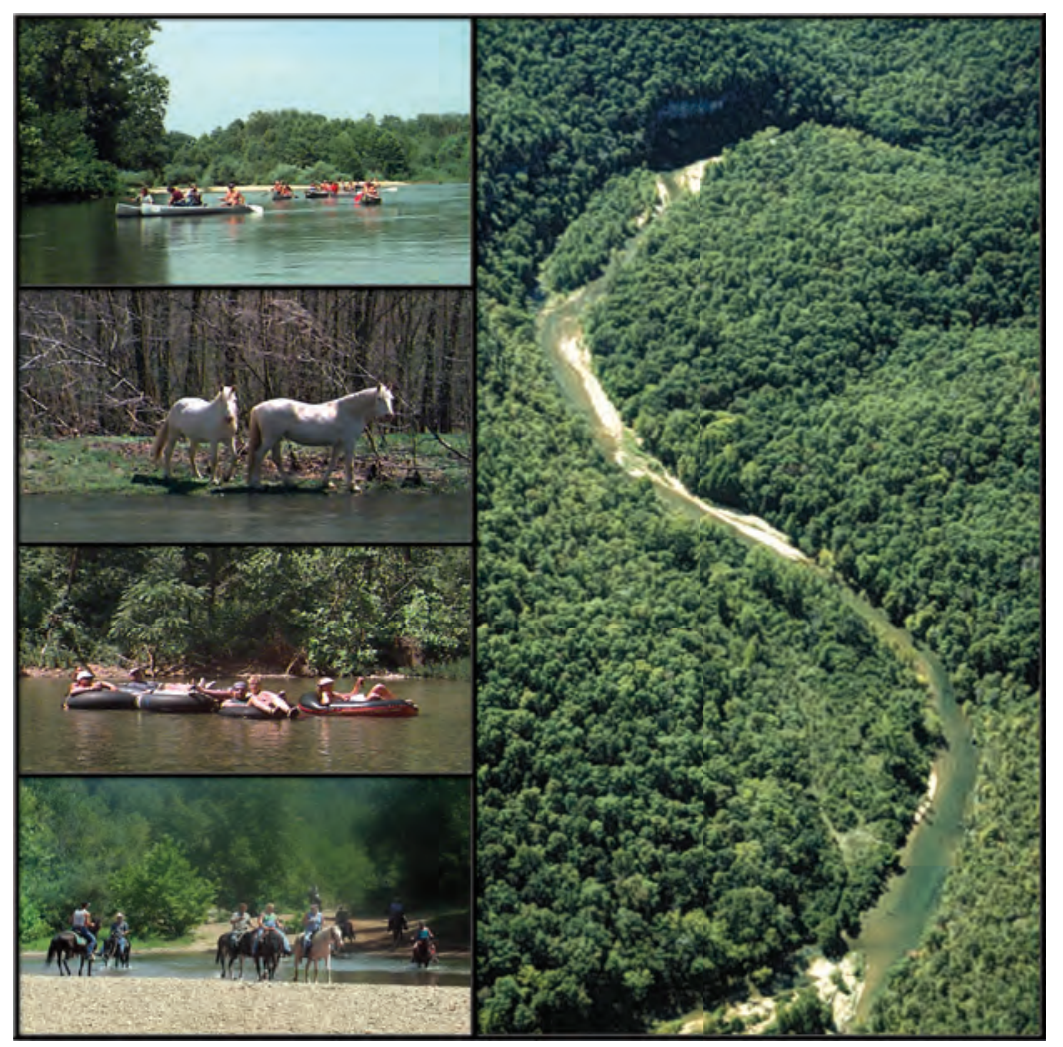

Scientific Investigations Report 2006-5161 
Cover photographs:

Upper Left: Canoeing on the Jacks Fork Second Left: Wild horses in the Ozark National Scenic Riverways

Third Left: Floating on the Jacks Fork

Bottom Left: Trail riders crossing the Jacks Fork

Right: The Jacks Fork immediately upstream from Alley Spring. Photograph courtesy of R.B. Jacobson, U.S. Geological Survey. 


\section{Assessment of Possible Sources of Microbiological Contamination in the Water Column and Streambed Sediment of the Jacks Fork, Ozark National Scenic Riverways, Missouri-Phase III}

By Jerri V. Davis and Miya N. Barr

Prepared in cooperation with the

National Park Service

Scientific Investigations Report 2006-5161 


\title{
U.S. Department of the Interior DIRK KEMPTHORNE, Secretary
}

\author{
U.S. Geological Survey \\ P. Patrick Leahy, Acting Director
}

\section{U.S. Geological Survey, Reston, Virginia: 2006}

For sale by U.S. Geological Survey, Information Services

Box 25286, Denver Federal Center

Denver, CO 80225

For more information about the USGS and its products:

Telephone: 1-888-ASK-USGS

World Wide Web: http://www.usgs.gov/

Any use of trade, product, or firm names in this publication is for descriptive purposes only and does not imply endorsement by the U.S. Government.

Although this report is in the public domain, permission must be secured from the individual copyright owners to reproduce any copyrighted materials contained within this report.

Davis, J.V., and Barr, M.N., 2006, Assessment of Possible Sources of Microbiological Contamination in the Water Columm and Streambed Sediments of the Jacks Fork, Ozark National Scenic Riverways, Missouri-Phase III: U.S. Geological Survey Scientific Investigations Report 2006-5161, 32 p. 


\section{CONTENTS}

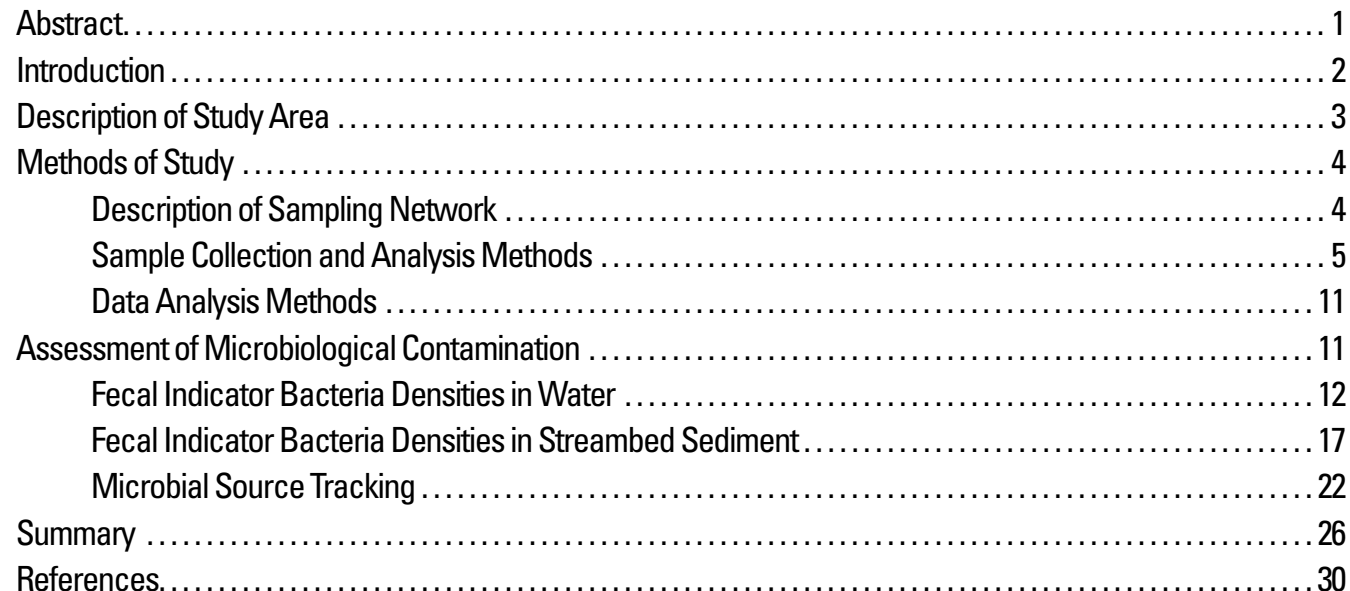

\section{Figures}

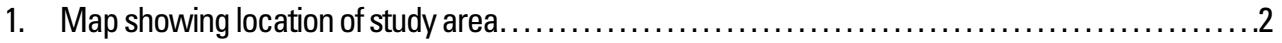

2. Graph showing departure from average monthly precipitation at Eminence, Missouri,

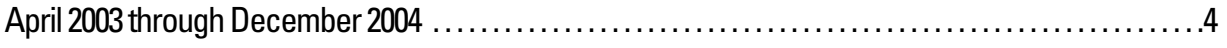

3. Map showing location of Jacks Fork sites sampled in study area during Phase III..............6

4. Graphs showing hydrologic condition during Jacks Fork sampling at two gaged sites,

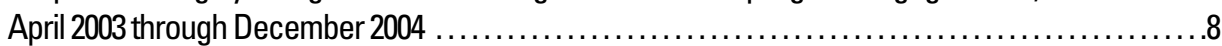

5. Flow chart showing growth, processing, and identification of Escherichia coliisolates using

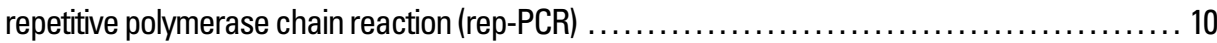

6. Photograph showing repetitive polymerase chain reaction DNA fingerprint patterns of

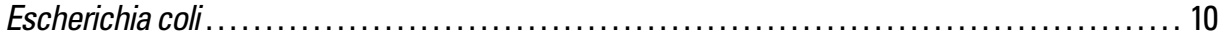

7. Photograph showing obtaining a known-host source sample from the Jacks Fork Basin........ 11

8. Graphs showing relation between fecal coliform density to Escherichia coli bacteria density in (A) water column and (B) streambed sediment. ........................... 13

9. Graphs showing fecal coliform bacteria density at selected Jacks Fork main-stem sites and

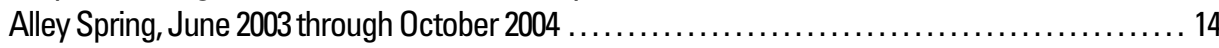

10. Boxplots showing fecal coliform density in (A) water column and (B) streambed sediment at main-stem and tributary sites and the Eminence Wastewater Treatment Plant on the

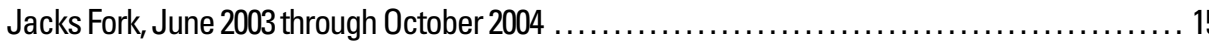

11-14. Graphs showing:

11. Fecal coliform bacteria density at site 110 during selected weekends and trail rides. 16

12. Fecal coliform bacteria density in water column and streambed sediment at Jacks Fork main-stem sites and Alley Spring, June 2003 through October 2004 ................ 18

13. Percentage of sand compared to silt and clay in streambed-sediment samples........... 23

14. Relations of fecal coliform bacteria density in streambed sediment to (A) fecal coliform bacteria density in water columm and (B) particle size

15. Pie charts showing percentage of Escherichia coliisolates in water-column samples assigned to various sources by repetitive polymerase chain reaction 


\section{Tables}

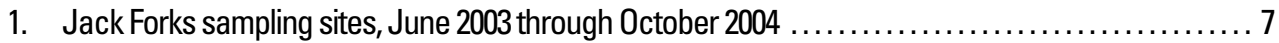

2. Sample collection dates, hydrologic conditions, and predominant river uses during sampling ......9

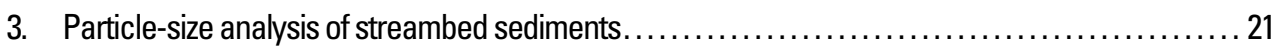

4. Number of Escherichia coliisolates in water-column samples assigned to various sources by

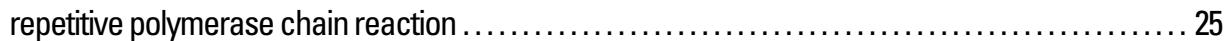

\section{Conversion Factors and Datum}

\begin{tabular}{|c|c|c|}
\hline Multiply & By & To obtain \\
\hline \multicolumn{3}{|c|}{ Length } \\
\hline inch (in.) & 2.54 & centimeter $(\mathrm{cm})$ \\
\hline inch (in.) & 25.4 & millimeter (mm) \\
\hline foot (ft) & 0.3048 & meter $(\mathrm{m})$ \\
\hline mile (mi) & 1.609 & kilometer (km) \\
\hline \multicolumn{3}{|c|}{ Area } \\
\hline square mile $\left(\mathrm{mi}^{2}\right)$ & 259.0 & hectare (ha) \\
\hline square mile $\left(\mathrm{mi}^{2}\right)$ & 2.590 & square kilometer $\left(\mathrm{km}^{2}\right)$ \\
\hline \multicolumn{3}{|c|}{ Volume } \\
\hline ounce, fluid (fl. oz) & 0.02957 & liter (L) \\
\hline pint (pt) & 0.4732 & liter (L) \\
\hline quart (qt) & 0.9464 & liter (L) \\
\hline gallon (gal) & 3.785 & liter (L) \\
\hline cubic inch $\left(\right.$ in $\left.^{3}\right)$ & 0.01639 & liter $(\mathrm{L})$ \\
\hline \multicolumn{3}{|c|}{ Flow rate } \\
\hline cubic foot per second $\left(\mathrm{ft}^{3} / \mathrm{s}\right)$ & 0.02832 & cubic meter per second $\left(\mathrm{m}^{3} / \mathrm{s}\right)$ \\
\hline inch per year (in/yr) & 25.4 & millimeter per year $(\mathrm{mm} / \mathrm{yr})$ \\
\hline \multicolumn{3}{|c|}{ Mass } \\
\hline ounce, avoirdupois (oz) & 28.35 & $\operatorname{gram}(\mathrm{g})$ \\
\hline pound, avoirdupois (lb) & 0.4536 & kilogram (kg) \\
\hline
\end{tabular}

Temperature in degrees Fahrenheit $\left({ }^{\circ} \mathrm{F}\right)$ may be converted to degrees Celsius $\left({ }^{\circ} \mathrm{C}\right)$ as follows:

${ }^{\circ} \mathrm{C}=\left({ }^{\circ} \mathrm{F}-32\right) / 1.8$

Concentrations of chemical constituents in water are given either in milligrams per liter $(\mathrm{mg} / \mathrm{L})$ or micrograms per liter ( $\mathrm{g} / \mathrm{L})$. 


\title{
Assessment of Possible Sources of Microbiological Contamination in the Water Column and Streambed Sediment of the Jacks Fork, Ozark National Scenic Riverways, Missouri-Phase III
}

\author{
By Jerri V. Davis and Miya N. Barr
}

\section{Abstract}

In 1998, a 5 river-mile reach of the Jacks Fork was included on Missouri's list of impaired waters as required by Section 303(d) of the Federal Clean Water Act. The identified pollutant on the Jacks Fork was fecal coliform bacteria. Potential sources of fecal contamination to the Jacks Fork include a wastewater-treatment plant, campground pit-toilet or septicsystem effluent, cross-country horseback trail riding, recreational boaters and swimmers, cattle, and wildlife. The length of the impaired reach was changed to 7 miles on the Missouri 2002 303(d) list because of data indicating the fecal coliform bacteria problem existed over a broader area.

The U.S. Geological Survey, in cooperation with the National Park Service, conducted a study to better understand the extent and sources of microbiological contamination within the Jacks Fork from Alley Spring to the mouth, which includes the 7-mile 303(d) reach. Identification of the sources would provide the National Park Service and the State of Missouri with the information needed to craft a solution of abatement, regulation, prevention, and mitigation with the end result being reduction of bacterial levels and removal of the Jacks Fork from the 303(d) list. Ten sites were sampled from June 2003 through October 2003 and from June 2004 through October 2004. Samples were collected from main-stem and tributary sites mostly during base-flow conditions during a variety of recreational season river uses. Water-column and streambed-sediment samples were analyzed for fecal coliform and Escherichia coli (E. coli) bacteria; sieve analysis also was performed on selected streambed-sediment samples to determine particle-size distributions at each sampling location.

During the sampling period, the Statewide whole-bodycontact recreation standard for fecal coliform (200 colonies per 100 milliliters of sample) was exceeded at two sites on August 6, 2003; at one site on October 8, 2003; and at two sites on August 11, 2004. Each of these exceedences occurred in samples collected when trail rides occurred. The Eminence Wastewater Treatment Plant may have contributed to one of the exceedences on August 6, 2003, at a site immediately down- stream from the plant because of large fecal coliform densities in the effluent.

To compare the effects of intense trail-ride activity and large volumes of recreational boaters and swimmers on fecal indicator bacteria densities, hourly sampling for fecal coliform and $E$. coli bacteria was done at site 110 on selected weekends when no trail rides were taking place, and on weekdays during trail rides. Generally, the fecal indicator bacteria densities tended to decrease or stay somewhat constant as the number of canoes, kayaks, and tubes passing site 110 increased. During trail rides, the fecal coliform bacteria densities generally tended to increase as the number of horses crossing the river increased, and decrease with a decrease in the number of horses crossing the river.

Because bacteria can survive longer in streambed sediments than in water, a source of bacteria in the water column could be from resuspension of accumulated bacteria from streambed sediments. Streambed-sediment samples were collected at all Jacks Fork main-stem and tributary sites and analyzed for fecal coliform and E. coli bacteria. The largest fecal coliform bacteria densities in the water column and streambed sediment generally occurred during trail rides. The relation of fecal coliform density in the water column to fecal coliform density in streambed sediment had a small positive correlation. The relation of fecal coliform density in streambed sediment to sediment particle size of less than 2,000 micrometers had a positive correlation.

Isolates of $E$. coli obtained from water samples collected at five sites were submitted for repetitive extragenic palidromic polymerase chain reaction (rep-PCR) analysis to identify presumptive sources of fecal indicator bacteria in the Jacks Fork. A known-host source library, consisting of sewage, horse, and cattle fecal samples collected within the Jacks Fork Basin, was developed. A total of $501 \mathrm{E}$. coli isolates were analyzed; 70 isolates were assigned to sewage, 118 to cattle, 132 to horses, and 181 unknown.

Results indicate that recreational users (including boaters and swimmers) are not the primary source of fecal coliform bacteria in the Jacks Fork; rather, the presence of fecal coliform bacteria is associated with other animals, of which horses are 


\section{Assessment of Possible Sources of Microbiological Contamination of the Jack Forks-Phase III}

the primary source. Increases in fecal coliform bacteria densities in the Jacks Fork are associated with cross-country horseback trail-riding events.

\section{Introduction}

The Ozark National Scenic Riverways (ONSR), the Nation's first federally protected riverway, was created by an Act of Congress on August 27, 1964, for "the purposes of conserving and interpreting unique scenic and other natural values and objects of historic interest, including preservation of parts of the Current River and the Jacks Fork in Missouri as freeflowing streams, preservation of springs and caves, management of wildlife, and provisions for use and enjoyment of the outdoor recreation resources thereof by the people of the United States" (Public Law 88-492). The primary natural resources protected by the ONSR are 134 river miles of the Current River and Jacks Fork (fig. 1). About 1.5 million people visit the ONSR annually for recreational purposes, including boating (primarily canoes and kayaks), swimming, tubing (use of personal flotation device to float downstream on the river), fishing, camping, hiking, caving, horseback riding, and hunting.

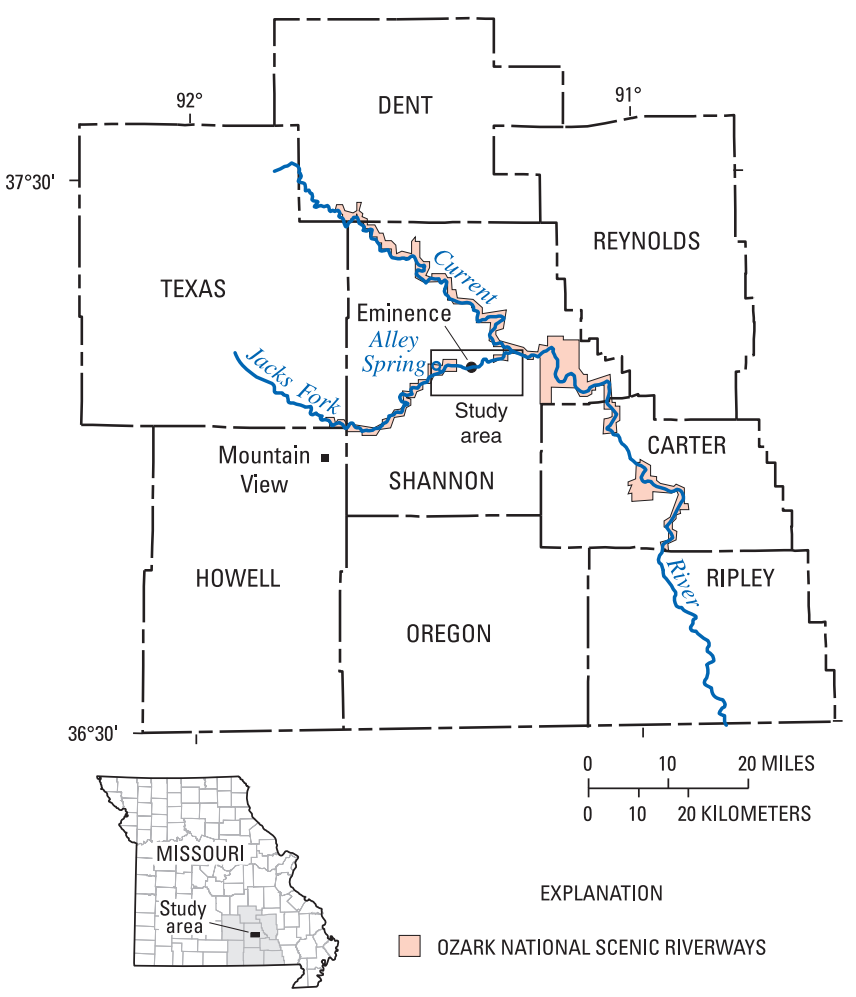

Figure 1. Location of study area.

The Jacks Fork is the largest tributary of the Current River, and similar to the Current River, has been classified as an Outstanding National Resource Water (Missouri Department of Natural Resources, 2000). Outstanding National Resource Waters have national recreational and ecological significance and receive special protection against any degradation in quality. These waters are classified in Missouri's Water-Quality Standards under "Tier III Waters", which allows no degradation of water quality (Missouri Department of Natural Resources, 2000). The Jacks Fork has been designated for the following five beneficial uses by the State of Missouri: livestock and wildlife watering, aquatic life protection, cool-water fishery, wholebody-contact recreation, and boating (Missouri Department of Natural Resources, 2000).

The intense recreational use of the Jacks Fork has caused concerns regarding the effects that this use might be having on the river. A river use management plan prepared by the National Park Service (NPS) (Sullivan and others, 1989) states that the increasing popularity of the recreational area has created concerns associated with greater competition for the use of a finite resource base. Also, because of inappropriate or intensive use, resource damage has increased in some areas. Concerns include crowding and increased conflicts between river users, the need to improve and provide more sanitation facilities, the proliferation of litter, congestion at river accesses and campgrounds, and balancing the need to protect water quality with the recreational needs of the public.

Section 303(d) of the Federal Clean Water Act requires that each State identify those stream segments with documented pollution problems for which existing pollution controls are not adequate to meet the Statewide water-quality standards. For these impaired stream segments, States are required to establish total maximum daily loads (TMDL) of the identified pollutant. A TMDL specifies the maximum amount of the identified pollutant allowed to be present in a water body, allocates allowable pollutant loads among sources, and provides the basis for attaining or maintaining water-quality standards within the affected water body.

In 1998, a 5 river-mile reach of the Jacks Fork was included on Missouri's list of impaired waters as required by Section 303(d) of the Federal Clean Water Act. The identified pollutant on the Jacks Fork was fecal coliform bacteria, whose presence in large numbers indicates contamination by fecal wastes of humans and other warm-blooded animals. In 1998 and through 2004, the Statewide fecal coliform standard for safe whole-body-contact recreation was a maximum of $200 \mathrm{col} / 100 \mathrm{~mL}$ (colonies per 100 milliliters) of sample (Missouri Department of Natural Resources, 2000). In the Jacks Fork Basin, the standard applied only to the main stem of the Jacks Fork during base-flow conditions during the recreational season from April 1 through October 31 . The length of the impaired reach was changed to 7 miles on the Missouri 2002 303(d) list because of data indicating the fecal coliform bacteria problem existed over a broader area.

A TMDL for the Jacks Fork was established by the State and approved by the U.S. Environmental Protection Agency (USEPA) (Missouri Department of Natural Resources, 2004). Because the Jacks Fork is designated as an Outstanding National Resource Water, the TMDL conforms to Missouri's "Tier III" anti-degradation policy, which allows no measurable increases in pollutant loading. For the Jacks Fork, this means that the ambient fecal coliform densities allowed by the State will be based on natural background conditions rather than on 
the Statewide water-quality standard. The determination was made through analysis of existing fecal coliform data that the ambient fecal coliform densities should not exceed a 30-day geometric mean of $25 \mathrm{col} / 100 \mathrm{~mL}$, and that no single sample should exceed $200 \mathrm{col} / 100 \mathrm{~mL}$, which is the Statewide wholebody-contact recreation standard (Missouri Department of Natural Resources, 2004).

Potential sources of fecal contamination to the Jacks Fork include the Eminence Wastewater Treatment Plant (WWTP), campground pit-toilet or septic-system effluent, cross-country horseback trail riding, recreational boaters and swimmers, cattle, and wildlife. Studies conducted by the U.S. Geological Survey (USGS) (Barks, 1978; Davis and Bell, 1998), Emrie (1986), NPS (National Park Service, written commun., 1997), and the Missouri Department of Natural Resources (MDNR) (1998) have indicated that intense recreational use is causing adverse affects on the water quality of the river, including fecal coliform bacteria densities that, on occasion, exceed the water-quality standard for whole-body-contact recreation.

Substantive regulatory efforts by the State to control and eliminate fecal coliform bacteria inputs to the Jacks Fork depend on identification of sources. The USGS, in cooperation with the NPS, conducted a three-phase study to better understand the extent and sources of microbiological contamination within the Jacks Fork from Alley Spring to the mouth (fig. 1), which includes the 7 river-mile 303(d) reach. Specific objectives of the three-phase study included determining the location and magnitude of fecal contamination (Phase I); establishing a water-quality sampling network to further document and understand the sources of fecal contamination (Phase II); and establishing sampling locations for routine long-term water-quality monitoring (Phase III). A summary of the Phase I study is described in Davis and Richards (2001), and a summary of the Phase II study is described in Davis and Richards (2002). Data collected during all three phases of the study are presented in Hauck and Nagel (2000, 2001, 2002, 2003, 2004, and 2005) and in Hauck and Harris (2006).

Phase I results indicated that fecal coliform bacteria are a concern in the Jacks Fork (Davis and Richards, 2001). Fecal coliform bacteria densities generally were larger in the 303(d) reach downstream from Eminence, and the Statewide standard for whole-body-contact recreation was exceeded at some sites in the 303(d) reach during the June and August 1999 synoptic surveys. Analysis of the fecal coliform bacteria data collected during Phase II (Davis and Richards, 2002) and III indicates bacteria densities not related to wet-weather flow were largest during trail rides. This occurred in water and streambed-sediment samples. Cross-country horseback trail rides are a popular activity within and adjacent to the ONSR for private horse owners and commercial trail-ride facilities. The largest of these facilities has supported an estimated 3,000 horses during weeklong trail rides that are held at least 7 weeks of the year. The reasons for the elevated fecal coliform bacteria densities during trail rides probably are related to four factors: (1) physical disturbance of streambed sediments causing resuspension of accumulated bacteria, (2) direct deposit of feces into the river, (3) fecal material carried into the river on the feet of animals, and (4) leakage of sewage effluent from an unknown source into the river.

Although it is evident from 5 years of sampling on the Jacks Fork that fecal coliform bacteria densities tend to increase during trail rides, the exact causes for the increase and the sources of the fecal coliform bacteria have not been positively identified. The specific objectives of the Phase III study are to characterize long-term trends in water column fecal coliform bacteria densities, characterize the role that streambed sediment plays in the storage and subsequent resuspension of fecal coliform bacteria in the Jacks Fork, and identify the sources of bacteria in the Jacks Fork. This report includes a description of the study area, including geology, climate, land use, and population; a description of the sampling network; a description of the sample collection and analysis methods; and an assessment of the possible sources of microbiological contamination of the Jacks Fork using statistical and graphical methods. Results for samples collected from June 2003 through October 2003 and from June 2004 through October 2004 are used in the assessment.

\section{Description of Study Area}

The Jacks Fork is in the Ozark Plateaus physiographic province (Fenneman, 1938) in southeast Missouri, which is an area characterized by deep, narrow valleys and sharp ridges. The river flows through mature karst topography and gains most of its base flow from springs. Karst topography (springs, sinkholes, and losing streams) and structural features (folds, faults, and fractures) greatly affect water quantity and quality. From its source in Texas County, the Jacks Fork drains an area of about $445 \mathrm{mi}^{2}$ (square miles); the average discharge of the Jacks Fork at Eminence, Missouri, is $462 \mathrm{ft}^{3} / \mathrm{s}$ (cubic feet per second) (Hauck and Nagel, 2005). Alley Spring, Missouri's seventh largest spring, discharges an average of about $125 \mathrm{ft}^{3} / \mathrm{s}$ into the Jacks Fork (Vandike, 1995) about 6 river miles upstream from the town of Eminence (fig. 1).

Josiah Bridge mapped and described the geology of much of the ONSR area (Barks, 1978). Geologic mapping of the Eminence and Alley Spring 7-1/2 minute quadrangles has been completed (Orndorff and others, 1999; D.J. Weary, U.S. Geological Survey, written commun., 2005). The ONSR area is situated on the southwest slope of the St. Francois Mountains. Precambrian igneous knobs crop out east of Eminence near the center of the ONSR. The igneous rocks mainly are rhyolite, a dense, fine-grained to porphyritic rock that generally is red, but may be gray or green. Streams and orifices of large springs are in the early Ordovician Gasconade Dolomite and late Cambrian Eminence and Potosi Dolomites. These cherty dolomites generally are several hundred feet thick, light gray to brown, and extremely soluble. Solution-enlarged openings throughout the formations store and transport large quantities of water. Soils produced from weathering of the dolomitic rock are deep red 


\section{Assessment of Possible Sources of Microbiological Contamination of the Jack Forks-Phase III}

clays with numerous small chert fragments. The Roubidoux Formation, which is composed of interbedded sandstones and dolomites, overlies the Gasconade Dolomite and caps the divides between most of the streams. Alluvial material in the Jacks Fork is comprised of boulders, cobbles, gravel, and sand overlying bedrock (Imes and Emmett, 1994).

The Jacks Fork area has a temperate climate, with average annual precipitation of about $42 \mathrm{in} . / \mathrm{yr}$ (inches per year). Average monthly precipitation generally is greatest in the spring [March through May; about 4 to 5 in./mo (inches per month)] and least in the late fall and winter (December through February; about 2 to 3 in./mo; Dugan and Peckenpaugh, 1985). Mean annual air temperature is $56^{\circ} \mathrm{F}$ (degrees Fahrenheit); the mean air temperature during January is $32^{\circ} \mathrm{F}$ and during July it is 78 ${ }^{\circ} \mathrm{F}$ (Dugan and Peckenpaugh, 1985). Monthly precipitation during the sampling period at Eminence, Missouri (June 2003 through October 2004), generally was below average (National Oceanic and Atmospheric Administration, 2003, 2004; fig. 2). No sample collection was done during November 2003 or late October and November 2004, when monthly precipitation was above average.

Land use in the Jacks Fork Basin primarily is forest (76 percent) and agricultural (23 percent). Second-growth, deciduous forest mixed with evergreen forest is predominant. About 92 percent of the agricultural land is used for pasture or hay production (Missouri Spatial Data Information Service, 2001). Cattle graze on bottomland pastures in the Jacks Fork Basin, and about 22,000 head of cattle were in the Jacks Fork Basin in 2002 (U.S. Department of Agriculture, 2002). The permanent population of people in the Jacks Fork Basin is about 8,000; the largest towns are Eminence $(548)$ and Mountain View $(2,430)$ (University of Missouri, 2001).

\section{Methods of Study}

To determine the microbiological contamination of the study area, a network of sampling sites was established. Water column and streambed-sediment samples were collected from these sites and analyzed for a variety of indicator bacteria and chemical constituents during base-flow conditions. This report only includes analysis of water column and streambed sediment fecal indicator bacteria data collected from June 2003 through October 2004. For purposes of this report, base flow is defined as stable flow unaffected by runoff.

\section{Description of Sampling Network}

The locations of microbiological contamination were determined in Phase I through three intensive synoptic surveys (Davis and Richards, 2001). A synoptic survey consists of the measurement of selected constituents at many sites during a brief period representative of a particular hydrologic or sea-

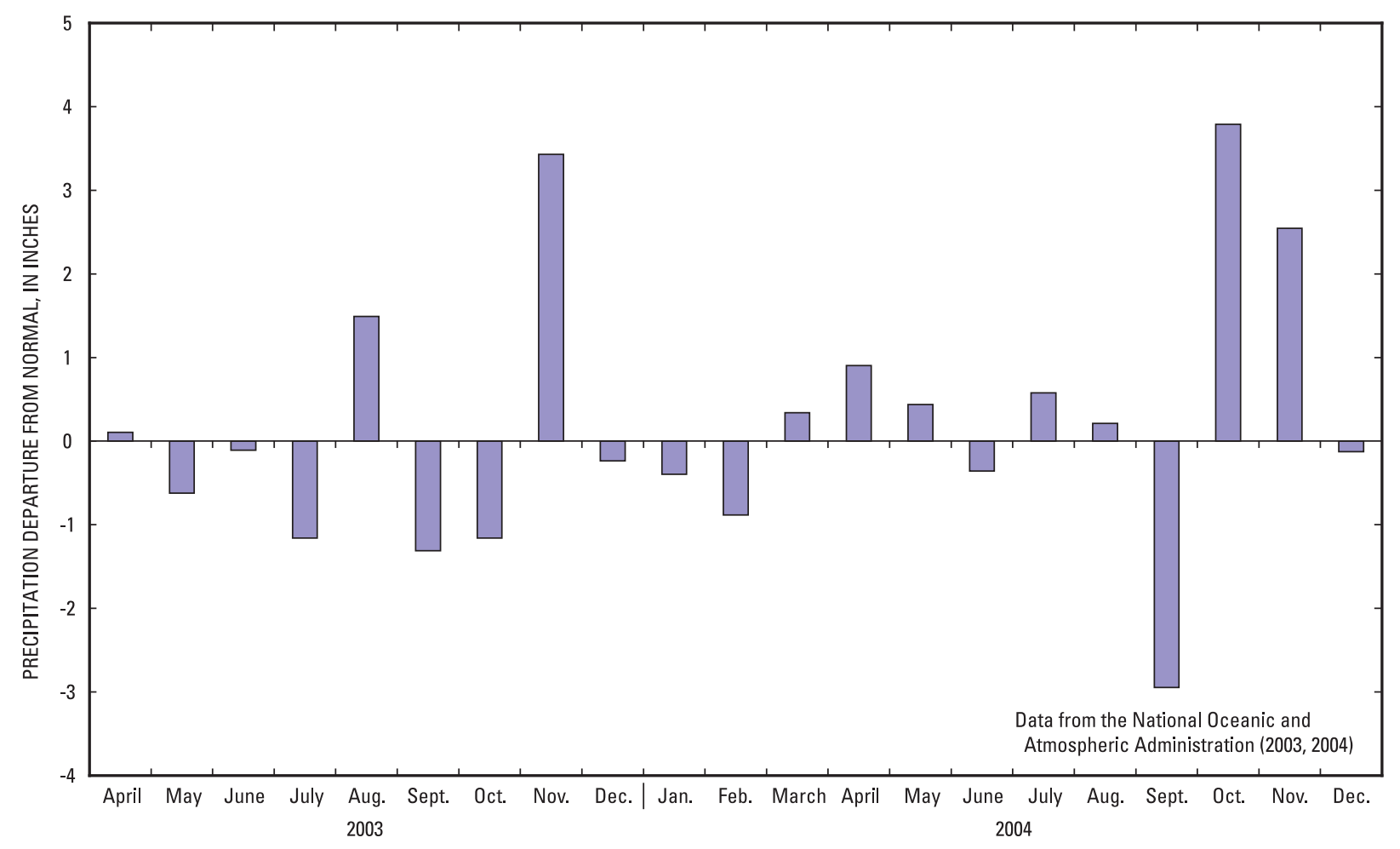

Figure 2. Departure from average monthly precipitation at Eminence, Missouri, April 2003 through December 2004. 
sonal condition. A reconnaissance of the Jacks Fork from the Alley Spring Campground to the mouth was done to locate sampling sites, locate potential sources of microbiological contamination, and map hydrologic features for inclusion in a geographic information system (GIS) database. Each location or feature was identified by geographic coordinates as determined by a global positioning system (GPS). Based on information collected during the reconnaissance, 42 sampling sites, including the Eminence WWTP, were selected (Davis and Richards, 2001). These sites were located on tributaries, spring branches, and on the main stem of the Jacks Fork near potential sources of microbiological contamination. The first intensive synoptic survey was done May 10 to 12,1999, during spring base-flow conditions at the beginning of the recreational season (defined by the State of Missouri as April 1 through October 31). The second and third intensive synoptic surveys were done during the recreational season on June 22 to 24 and August 10 to 12, 1999, during early-summer and late-summer base-flow conditions.

To further understand the sources of microbiological contamination in the Jacks Fork, sampling was done during Phase II (November 1999 through December 2000) at 16 of the 42 sites from Phase I (Davis and Richards, 2002). Samples were collected primarily during base-flow conditions during a variety of nonrecreational and recreational season river uses, including boating, swimming, tubing, camping, and horseback riding.

Phase III long-term water-quality monitoring was continued (January 2001 through August 2005) at 10 of the 16 sites sampled during Phase II (fig. 3; table 1). Starting in June 2003 through October 2004 both streambed-sediment samples and water-column samples were collected for the analysis of selected fecal indicator bacteria. Samples were collected primarily during base-flow conditions during a variety of recreational season uses, including boating, swimming, tubing, camping, and horseback riding. River conditions were affected by runoff when samples were collected June 2 to 4 and June 9 to 11, 2003. Continuous record streamflow-gaging stations are located on the Jacks Fork immediately downstream from site 5 (USGS station number 07065495) and at Eminence (site 60, USGS station number 07066000 ; fig. 3). The hydrologic conditions at the two gaged sites during Phase III sampling are shown in figure 4 and listed in table 2. Although the recreational season is defined as occurring between April 1 and October 31, most recreational river use takes place between late May and early September.

\section{Sample Collection and Analysis Methods}

Ten sites were sampled June through October of 2003 and 2004 during a variety of recreational season river uses, including boating, swimming, tubing, camping, and horseback riding (table 2). Water samples were collected and analyzed by the USGS at each site for indicator bacteria [fecal coliform and Escherichia coli (E. coli)] using the membrane-filtration procedure described in Myers and Wilde (2003). Indicator bacteria samples were collected in a sterile $500-\mathrm{mL}$ (milliliter) polypropylene bottle by facing the bottle into the current and dipping quickly into the stream at three to five equally spaced locations in the stream cross section. The samples were placed on ice and held a maximum of 6 hours until processing. Densities of indicator bacteria can be quite variable at the site; therefore, up to three sample volumes ranging from 10 to $100 \mathrm{~mL}$ were filtered from individual stream samples to ensure that at least one filter would have bacterial colonies in the ideal counting range (20 to 60 colonies per filter of fecal coliform and 20 to 80 colonies per filter of E. coli.) (Myers and Wilde, 2003). The multiple sample volumes also serve as replicate samples to monitor analytical precision. m-FC agar-based selective growth media was used to analyze fecal coliform, and m-TEC agar-based selective growth media was used to analyze $E$. coli. Sterile buffered water (buffer) was used to dilute samples and to rinse the membranefiltration apparatus. Phosphate buffer is used for fecal coliform, and saline buffer is used for $E$. coli. Reagent blanks were run twice each day using buffer to check for contamination of equipment and reagents. No fecal coliform or E. coli bacteria were present on the reagent blanks.

Samples for the enumeration of fecal indicator bacteria (fecal coliform and E. coli) in streambed sediments were collected at selected sites using a modification of the membrane filtration procedure described in Francy and Darner (1998). Streambed sediments, which consist primarily of gravel, sand, silt, and clay, were collected by scooping the stream bottom with a sterile wide-mouth $250-\mathrm{mL}$ polypropylene jar. The jars were kept covered until they touched the stream bottom to minimize contamination by the overlying water. Excess water was poured out of the jar, and the cap replaced. Streambed sediments were subsampled in three locations in the stream cross section. The samples were placed on ice and held no more than 10 hours before processing.

The three streambed-sediment subsamples were composited in a sterile 1-L (liter) polypropylene bottle and stirred with a sterile, disposable spoon to ensure thorough mixing. A representative streambed-sediment sample was extracted from the $1-\mathrm{L}$ bottle and placed in a sterile $250-\mathrm{mL}$ polypropylene bottle and weighed. Buffer water was added to the bottle, and the total weight recorded. The $250-\mathrm{mL}$ bottles were placed on a wristaction shaker for 10 minutes, and then the samples were placed on ice and allowed to settle for approximately 10 hours. The shaking time for this study was decreased to 10 minutes from 45 minutes (Francy and Darner, 1998) to shorten sample processing time, and the settling time was increased from 30 seconds (Francy and Darner, 1998) to 10 hours to facilitate removal of fine sediments, which would interfere with the analysis of fecal indicator bacteria by the membrane-filtration method. After the settling period, the buffer mixture was decanted from the 250$\mathrm{mL}$ bottle into another sterile $250-\mathrm{mL}$ bottle. Fecal coliform and E. coli densities were determined from this buffer mixture using the membrane-filtration procedure described in Myers and Wilde (2003). Densities of indicator bacteria also can be quite variable in streambed sediment; therefore, up to three sample volumes ranging from 1 to $10 \mathrm{~mL}$ were filtered from the individual streambed-sediment sample extracts to ensure that at least one filter would have bacterial colonies in the ideal count- 


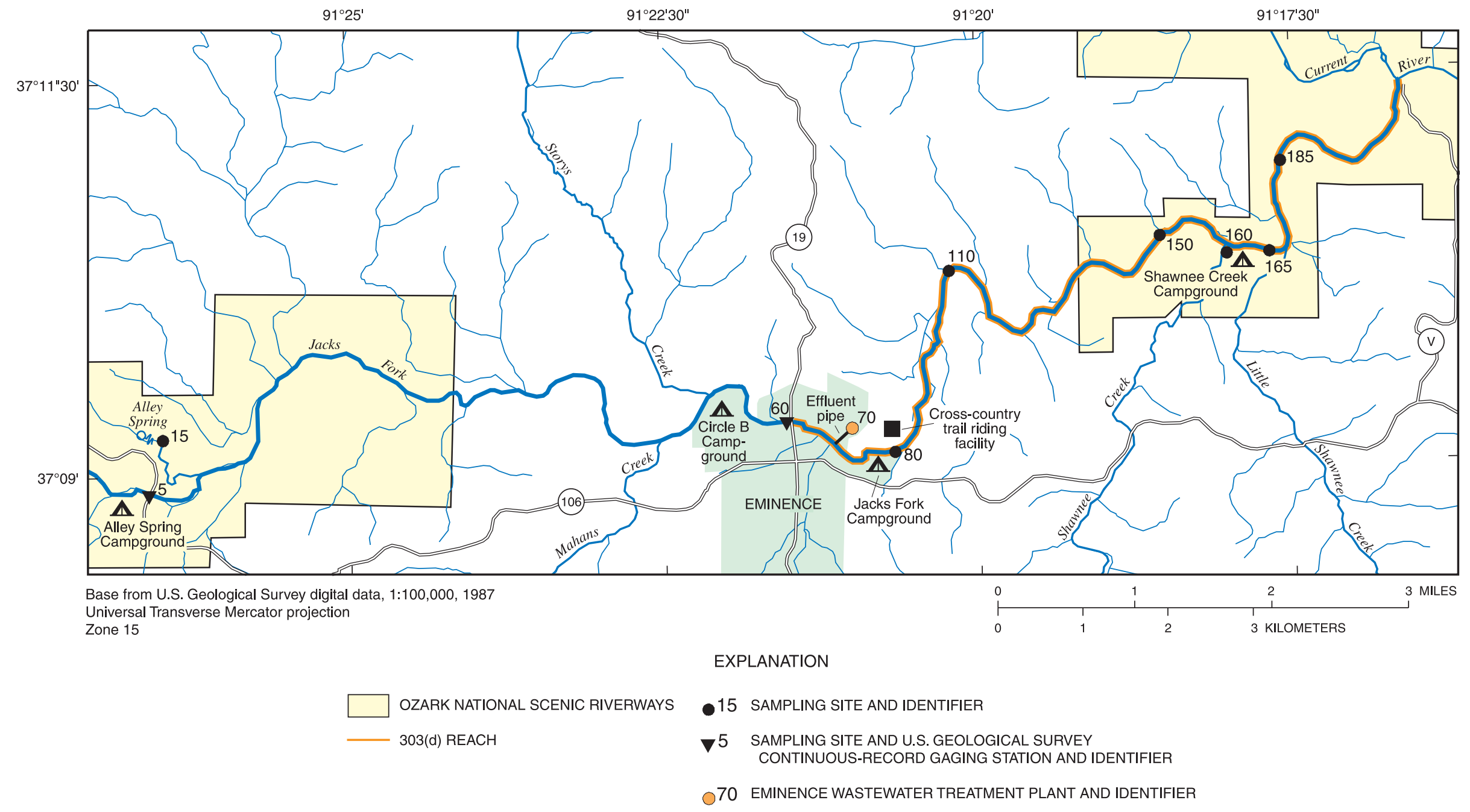

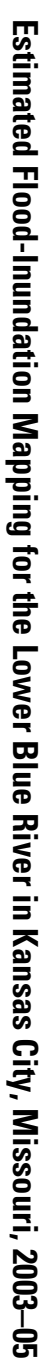

Figure 3. Location of Jacks Fork sites sampled in study area during Phase III. 
Table 1. Jacks Fork sampling sites, June 2003 through October 2004.

[USGS, U.S. Geological Survey; ddmmss, degrees. minutes, seconds; $\mathrm{mi}^{2}$, square miles; NA, not applicable]

\begin{tabular}{rrrrrr}
\hline $\begin{array}{c}\text { Site } \\
\text { number } \\
\text { (fig. 3) }\end{array}$ & $\begin{array}{c}\text { USGS } \\
\text { station number }\end{array}$ & \multicolumn{1}{c}{ Site name } & $\begin{array}{c}\text { Latitude } \\
\text { (ddmmss) }\end{array}$ & $\begin{array}{c}\text { Longitude } \\
\text { (ddmmss) }\end{array}$ & $\begin{array}{c}\text { Drainage } \\
\text { area } \\
(\mathrm{mi})^{2}\end{array}$ \\
\hline 5 & 370857091265901 & Jacks Fork above Alley Spring & 370857 & 912659 & 302 \\
15 & 370901091262001 & Alley Spring below Alley & 370914 & 912629 \\
60 & 07066000 & Jacks Fork at Eminence & 370915 & 912129 & 404 \\
70 & 370915091210101 & Eminence Wastewater Treatment Plant & 370915 & 912101 & NA \\
80 & 370905091204001 & Jacks Fork above 2nd unnamed hollow below Eminence & 370905 & 912040 & 406 \\
110 & 371014091201301 & Jacks Fork above Lick Log Hollow below Eminence & 371014 & 912013 & 409 \\
150 & 371026091183301 & Jacks Fork above Powell Spring above Two Rivers & 371026 & 911833 & 413 \\
160 & 371019091180101 & Shawnee Creek above Two Rivers & 371019 & 911801 & 20.0 \\
165 & 371020091174101 & Jacks Fork above Little Shawnee Creek above Two Rivers & 371020 & 911741 & 433 \\
185 & 371054091173501 & Jacks Fork below 3rd unnamed hollow above Two Rivers & 371054 & 911735 & 444 \\
\hline
\end{tabular}

${ }^{a}$ Recharge area of Alley Spring is estimated to be greater than 125 square miles (Aley and Aley, 1987).

ing range, as discussed previously. The fecal coliform and E. coli densities in streambed sediment are reported as col/g (colonies per gram of dry weight sediment) (Francy and Darner, 1998). Sieve analysis also was performed on selected samples on the remaining streambed sediment to determine particle-size distributions at each sampling location. The composited sediment was oven dried at $100^{\circ} \mathrm{C}$ and processed through a series of sieves to determine the percentage of sediment finer than 2,000, 250, and $63 \mu \mathrm{m}$ (micrometer) (Guy, 1969).

During the first recreational sampling period (June through October 2003), approximately $125 \mathrm{~g}$ (grams) of streambed sediment and $100 \mathrm{~mL}$ of buffer water were put in two separate 250-mL sample bottles for processing. Francy and Darner (1998) used $20 \mathrm{~g}$ of sediment and $200 \mathrm{~mL}$ of saline buffer; however, because of the gravel content in Jacks Fork streambed sediments, $20 \mathrm{~g}$ of sediment contained only minimal fine material, which is where fecal indicator bacteria would be expected to adhere. Phosphate buffer was added to one of the subsamples to isolate fecal coliform, and saline buffer was added to the other subsample to isolate $E$. coli. Initially, fecal coliform and $E$. coli were analyzed from both the phosphate and saline subsamples. After further investigation, it was determined that the saline buffer produced the best results for both fecal coliform and E. coli. Small clay particles tended to remain flocculated in the phosphate buffer, which inhibited settling during the 10-hour period. The optimum quantities of streambed sediment and saline buffer water for ease of analysis and maximum recovery eventually were determined to be $75 \mathrm{~g}$ and $150 \mathrm{~mL}$, and this approach was utilized for samples collected June through October, 2004.

A technique known as microbial source tracking (MST) was used in this study to help identify the possible primary sources of $E$. coli bacteria in water-column samples. MST has been shown to be useful in discriminating between human and nonhuman sources of $E$. coli in water samples (Hartel and others, 1999; Parveen and others, 1999; Schlottmann and others, 2000; Carson and others, 2001; Schumacher, 2001, 2003; McLellan, 2004; Stoeckel and others, 2004). A number of MST methods for differentiating between human and nonhuman sources of $E$. coli are available, including the DNA-fingerprinting technique called repetitive extragenic palindromic polymerase chain reaction (rep-PCR).

Water samples for rep-PCR analysis were collected from selected sites using the technique described previously for indicator bacteria and sent by overnight mail to the University of Missouri, Columbia (UMC), College of Veterinary Medicine, MST laboratory. The laboratory uses a rep-PCR method modified from Dombek and others (2000). The multi-step process involves isolating and growing pure culture of E. coli bacteria from the environmental sample, lysing the isolates with a reagent, followed by PCR amplification of the DNA between adjacent repetitive elements with the BOX A1R primer, and performing electrophoresis on the PCR products to produce the DNA banding patterns (figs. 5 and 6). The resulting banding patterns of isolated $E$. coli from the environmental sample are compared to the banding patterns of isolated E. coli from known-host source feces for similarity and possible identification using pattern recognition computer software (Bionumerics software; Applied Maths, Kortrijk, Belgium). Pairwise similarity coefficients between the rep-PCR profiles generated for each E. coli isolate were calculated by the curve-based Pearson correlation method for discriminant analysis (Carson and others, 2003). Classification of isolates was done by maximum similarity, in which an environmental $E$. coli isolate was 


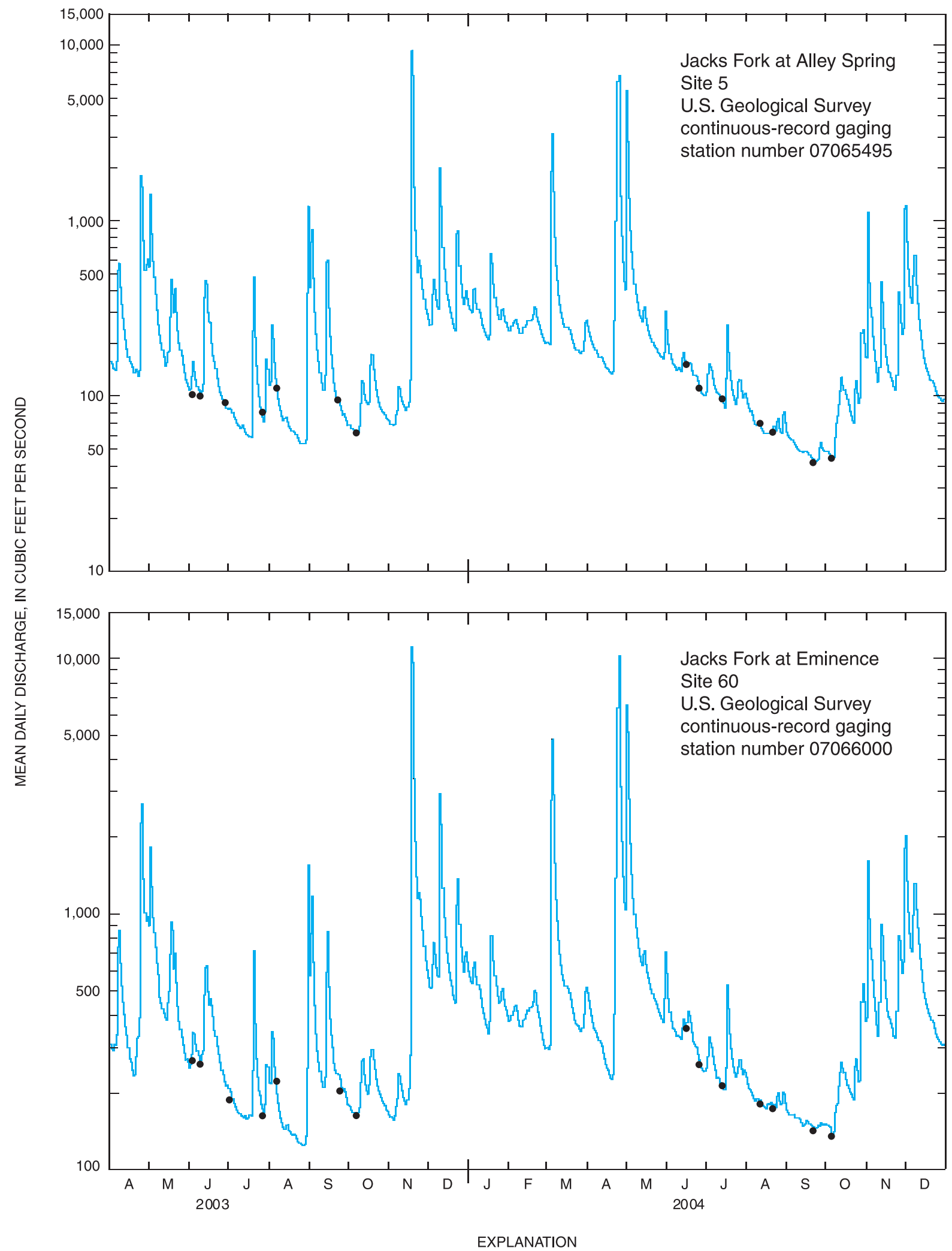

- WATER SAMPLE COLLECTED

Figure 4. Hydrologic condition during Jacks Fork sampling at two gaged sites, April 2003 through December 2004. 
Table 2. Sample collection dates, hydrologic conditions, and predominant river uses during sampling.

\begin{tabular}{|c|c|c|}
\hline Date of sample collection & Hydrologic condition & River use \\
\hline June $2-4,2003$ & Base flow and rising stage ${ }^{a}$ & Early recreational season \\
\hline June 9-11, 2003 & Base flow and rising stage ${ }^{b}$ & Trail ride, boating ${ }^{\mathrm{c}}$, swimming, tubing ${ }^{\mathrm{d}}$, and camping \\
\hline June 28, 2003 & Base flow & Boating, swimming, tubing, and camping \\
\hline July 26, 2003 & Base flow & Boating, swimming, tubing, and camping \\
\hline August 5-6, 2003 & Base flow & Trail ride, boating, swimming, tubing, and camping \\
\hline September 23, 2003 & Base flow & Late recreational season \\
\hline October 7-8, 2003 & Base flow & Trail ride and late recreational season \\
\hline June 15, 2004 & Base flow & Trail ride, boating, swimming, tubing, and camping \\
\hline June 26, 2004 & Base flow & Boating, swimming, tubing, and camping \\
\hline July 13, 2004 & Base flow & Boating, swimming, tubing, and camping \\
\hline August 10-11, 2004 & Base flow & Trail ride, boating, swimming, tubing, and camping \\
\hline August 21, 2004 & Base flow & Boating, swimming, tubing, and camping \\
\hline September 21, 2004 & Base flow & Late recreational season \\
\hline October 5, 2004 & Base flow & Trail ride and late recreational season \\
\hline
\end{tabular}

\footnotetext{
${ }^{\text {a }}$ Base-flow conditions existed on June 2. Rainfall on June 2 resulted in runoff. At the time the study was conducted, the whole-body-contact recreation standard did not apply during wet-weather flow.

${ }^{b}$ Base-flow conditions existed on June 9. Rainfall on the morning of June 10 resulted in runoff. At the time the study was conducted, the wholebody-contact recreation did not apply during wet-weather flow.

${ }^{\mathrm{c}}$ Primarily canoes and kayaks.

${ }^{\mathrm{d}}$ Use of personal flotation device to float downstream on the river.
}

assigned to the source of the known-host source isolate to which it had the greatest similarity, provided that the similarity of the match was 80 percent or higher. Accuracy of this classification strategy was measured by jackknife analysis, also known as cross-validation (Carson and others, 2003). Rates of correct classification (RCC) were calculated from the information provided by the cross-validation.

Rep-PCR analysis involves using multivariate statistical methods to compare patterns in large data sets. The method compares the similarity of patterns from unknown environmental isolates of E. coli to known patterns in a watershed database. For this study, a known-host source library was developed consisting of patterns from $E$. coli isolates obtained from sewage (215 isolates), cattle (229 isolates), and horse (215 isolates) feces samples collected within the Jacks Fork Basin from August 2002 through March 2005. Sewage samples were collected in sterile, $500-\mathrm{mL}$ polypropylene bottles from pit toilets located in the Shawnee Creek Campground and from the outflows of the Eminence WWTP and a small WWTP located at the Alley Spring Campground (fig. 3). Horse and cattle feces were collected by scooping a small quantity of fresh feces with a sterile spoon and putting the sample into a Whirlpak bag (fig. 7). Cattle feces samples were collected from multiple individuals from four herds in the Jacks Fork Basin. Horse feces samples were collected during trail rides from multiple individuals. Although some of these individuals may reside in the Jacks Fork Basin, most probably reside in areas outside of the basin. All known-host source samples were kept chilled at $4{ }^{\circ} \mathrm{C}$ until delivery to the UMC-MST laboratory.

DNA fingerprinting techniques, such as ribotyping and rep-PCR, rely on the assumption that the DNA-fingerprints of E. coli from various animal species are largely unique; however, variability of $E$. coli strains within a single animal group occurs both temporally and geographically. Hartel and others (2002) determined that ribotypes for cows in Idaho and Georgia differed significantly. Also, E. coli strains potentially are shared between various animals. Sargeant and others (1999) indicated that wild deer foraging in fields where dairy cows were pastured became colonized with the identical strain of $E$. coli carried by the cows. By populating the known-host source library with sources obtained over a relatively short timeframe in the Jacks Fork Basin, the effects caused by temporal and geographic variability should be minimized to the extent possible, considering that many of the horse isolates in the library originate from individuals that reside outside of the basin.

Sewage, horses, and cattle were chosen for inclusion in the known-host source library because they were the expected predominant sources of fecal contamination. This concept was 


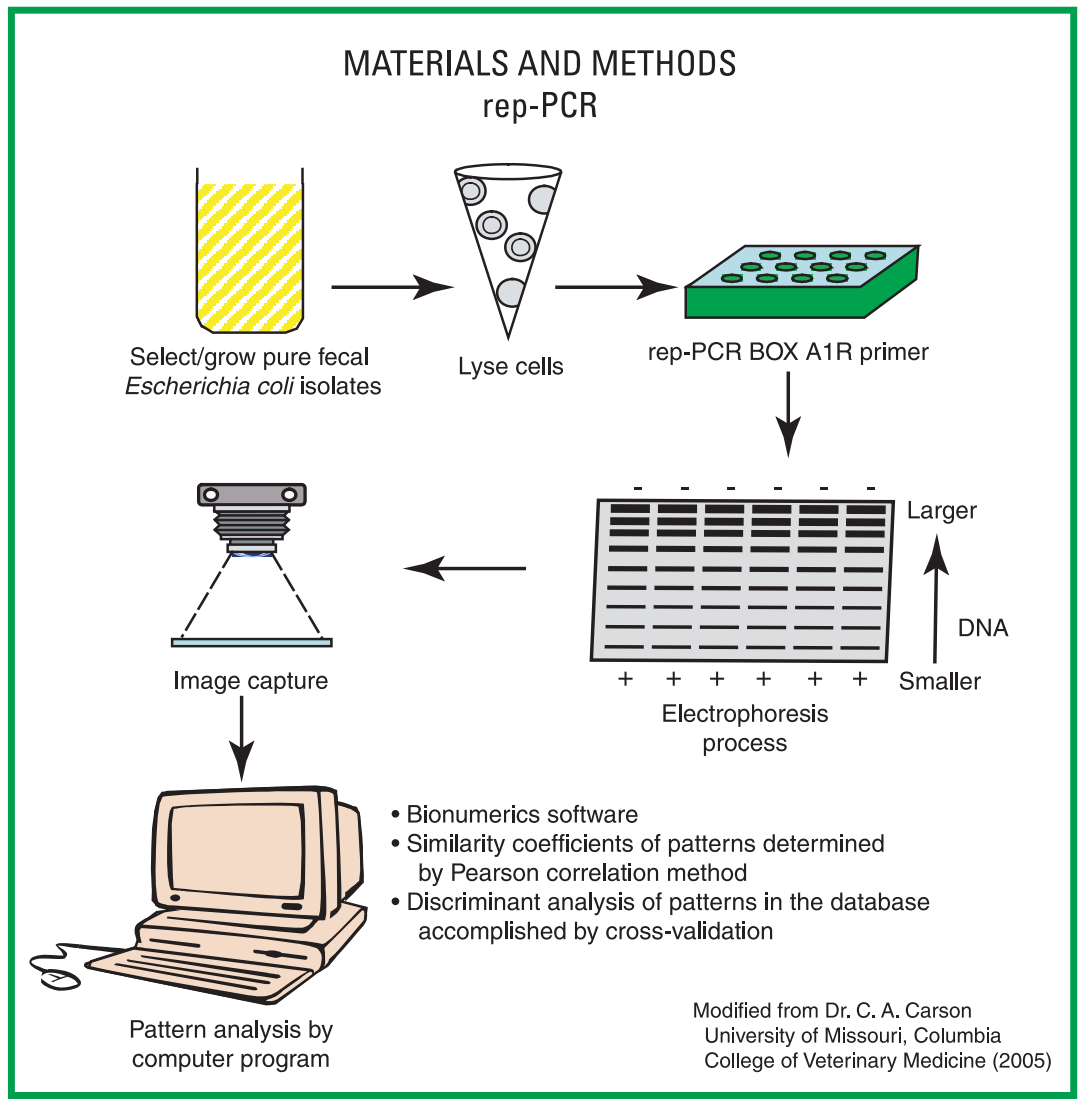

Figure 5. Growth, processing, and identific ation of Escherichia coli isolates using repetitive polymerase chain reaction (rep-PCR).

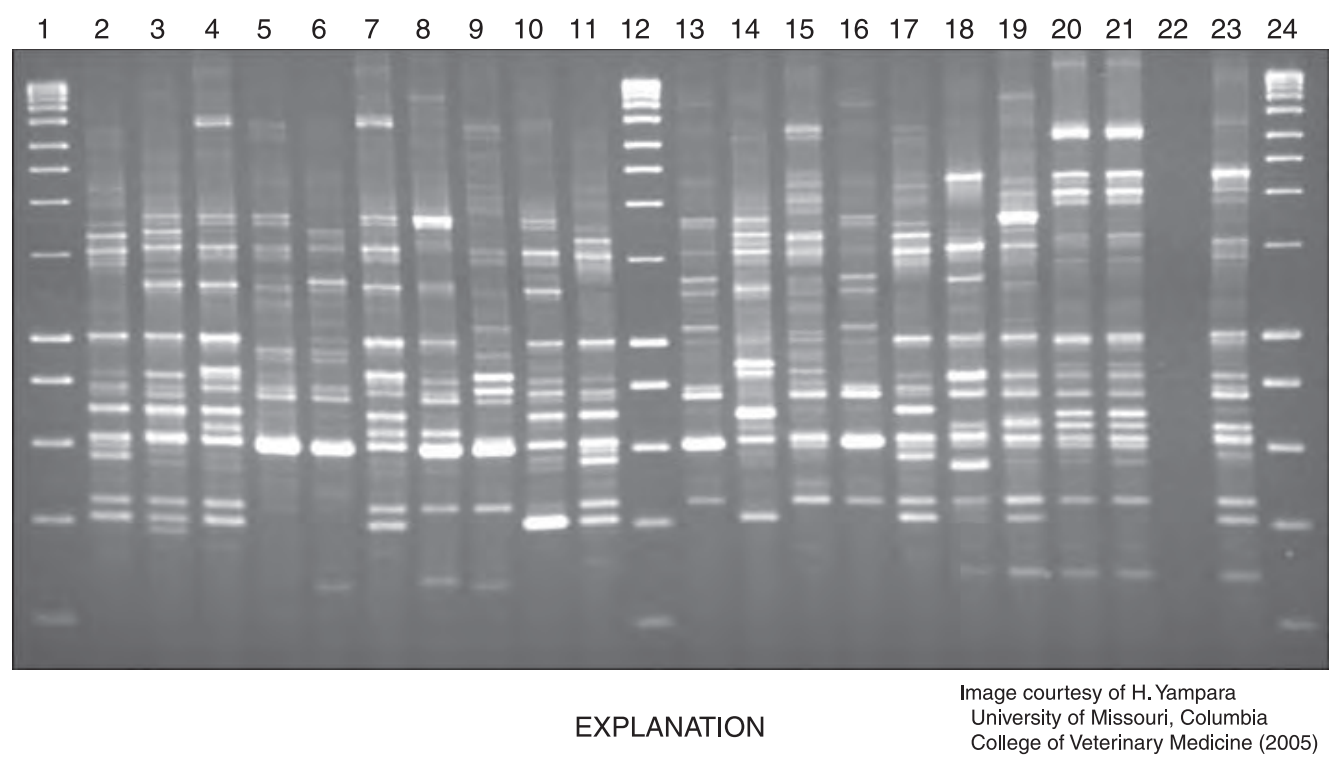

1 NUMBER IS LANE IDENTIFICATION
Lane 1, 12, and 24
Lane 22
Known molecular-weight ladders
Lane 2 to 11,13 to 21 , and 23
Blank
Banding patterns for individual Escherichia coli isolates

Figure 6. Repetitive polymerase chain reactionDNA fingerprint patterns of Escherichia coli. 


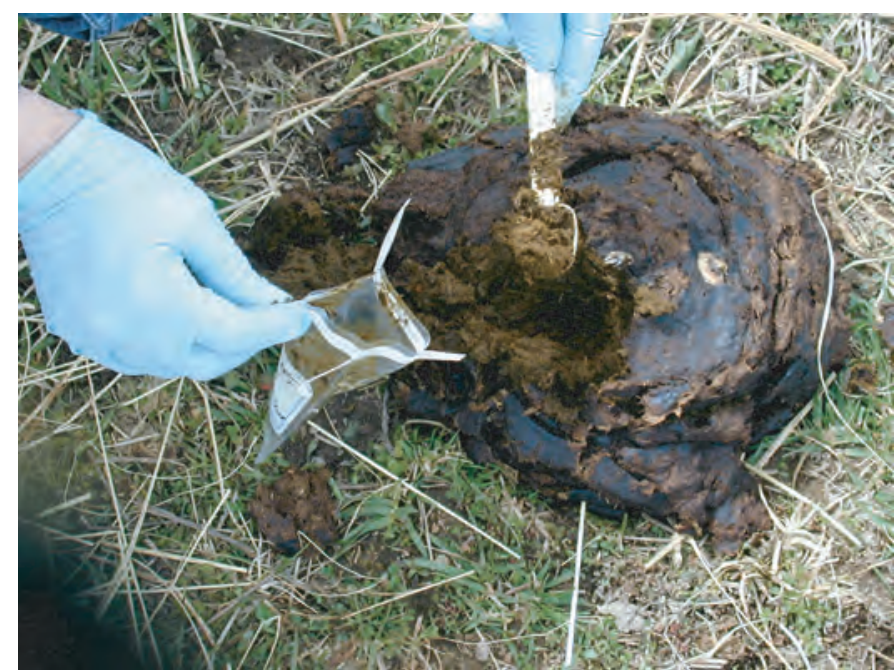

Figure 7. Obtaining a known-host source sample from the Jacks Fork Basin.

based on the presence of all of these sources in the study area and the previous ribotyping results from Phase II (Davis and Richards, 2002). Matching of patterns of environmental E. coli isolates with library patterns was made using discriminant analysis, and a library pattern was considered to be a match if the maximum similarity to the unknown was 80 percent or higher. If no library pattern matched the environmental isolate, it was classified as unidentified, and may have originated from domesticated animals such as pigs, dogs, cats, or chickens; wild animals such as deer, raccoons, geese, and ducks; or horses from outside of the Jacks Fork Basin. As additional patterns are added to the database of "known" patterns, the representativeness of the library increases and accuracy of the method improves. Interpretation of these data was made in conjunction with other data and information.

\section{Data Analysis Methods}

The indicator bacteria data were evaluated to determine factors affecting their occurrence in the Jacks Fork and tributaries. A detailed analysis of the Phase II physical property (dissolved oxygen, $\mathrm{pH}$, specific conductance, and temperature) and nutrient (dissolved nitrite plus nitrate and total phosphorus) data was done and presented in Davis and Richards (2002). Results of the analysis indicated that most variations in physical property values or nutrient concentrations were related to seasonal changes, time of day the sample was collected, or hydrologic conditions and are not related to certain recreational activities. Similar results were obtained when the Phase III physical property and nutrient data were analyzed; those results will not be presented in this report.

Fecal coliform densities in the water column are compared to the Statewide whole-body-contact recreation standard of 200 $\mathrm{col} / 100 \mathrm{~mL}$; not to a geometric mean of $25 \mathrm{col} / 100 \mathrm{~mL}$ as specified in the TMDL (Missouri Department of Natural Resources,
2004). To calculate the geometric mean, the analysis must include at least four equally spaced samples collected within a 30-day time frame. The data collected for this study did not fit these criteria and are, therefore, compared to the Statewide standard. The TMDL indicates that no single sample should exceed the Statewide standard (Missouri Department of Natural Resources, 2004).

The distribution of selected indicator bacteria data was graphically displayed using side-by-side boxplots (Helsel and Hirsch, 1992). The plots show the center of the data (median - the center line of the box), the variation (interquartile range - the box height), the skewness (quartile skew-the relative size of the box halves), and the presence or absence of unusual values ("outside" or "far-out" values). The boxplot consists of a center line (the median) splitting a rectangle defined by the interquartile range (25th to 75 th percentiles) and whiskers that extend to the last observation within one step beyond either end of the box ("adjacent values"). A step equals 1.5 times the height of the box. Observations between one and two steps from the box in either direction are plotted with an asterisk ("outside values"), and observations farther than two steps beyond the box are plotted with a circle ("far-out values"). If the median equals the 25 th percentile, no center line will be present. If the median equals the 25 th and 75 th percentiles, the box is represented by a line. Boxplots constructed for sites with censored data (data reported as less than some threshold) were modified by making the lower limit of the box equal to the minimum reporting level of $1 \mathrm{col} / 100 \mathrm{~mL}$.

The nonparametric Kruskal-Wallis analysis-of-variance test (Helsel and Hirsch, 1992) was used to test for differences in the distributions of the data from Alley Spring and the seven Jacks Fork main-stem sampling sites. The distributions were considered significantly different from one another if the probability (p-value) that the observed difference occurred by chance was less than 5 percent (less than 0.05). If a statistically significant difference was detected between the sites, individual differences were evaluated by applying Tukey's multiple comparison test to the rank-transformed data (Helsel and Hirsch, 1992). Spearman's rho correlation (Helsel and Hirsch, 1992) was used to evaluate the relation between fecal coliform densities in the water column and number of canoes, kayaks, and tubes or number of horses crossing the river at site 110 . In addition, the relation of indicator bacteria densities in water and streambed sediment and of streambed sediment to sediment particle size distribution also was evaluated using Spearman's rho correlation.

\section{Assessment of Microbiological Contamination}

Measuring fecal indicator bacteria densities in water can provide an estimate of the sanitary quality of water. The density of these bacteria is one indicator of whether or not water is safe for whole-body-contact recreation or consumption and/or free from disease-causing organisms. Indicator bacteria typically are 
not disease causing, but two indicator organisms, E. coli and enterococci, have been correlated to incidence rates of gastrointestinal illness (U.S. Environmental Protection Agency, 1986). Common sources of fecal indicator bacteria include municipal wastewater-treatment effluents that have not been completely disinfected; septic tanks; animal wastes from feedlots, barnyards, and pastures; and stormwater. The fecal indicator bacteria used in this study are bacteria of the fecal coliform group and E. coli, both of which commonly are present in the intestinal tracts of warm-blooded animals. E. coli are strictly inhabitants of the gastrointestinal tracts of warm-blooded animals, and their presence in water is direct evidence of fecal contamination from warm-blooded animals and the possible presence of pathogens (Dufour, 1977).

Because fecal bacteria normally inhabit the gastrointestinal tracts of warm-blooded animals, they die off within days of exposure to the relatively cold environment of streams; however, fecal bacteria have been shown to survive from a few hours to a few days in streams, and a few weeks to a few months in streambed sediments (Roszak and Colwell, 1987; Doyle and others, 1992; Pommequy and others, 1992; Myers and others, 1998). Bacterial decay results from cell starvation, predation by stream protozoans, and destruction by the ultraviolet component of sunlight and other physicochemical processes such as chlorination (U.S. Environmental Protection Agency, 1985; Roszak and Colwell, 1987).

To determine the possible sources of fecal bacteria in the Jacks Fork, multiple lines of evidence are necessary, including microbiological, physical, chemical, and hydrological data and ancillary information on land, water, and recreational use of the resource. A complete analysis of the fecal coliform data is presented in the following sections. Density distributions for $E$. coli are similar to those for fecal coliform and will not be discussed. The relations of fecal coliform densities to $E$. coli densities in the water column and in streambed sediments are shown in figure 8 .

\section{Fecal Indicator Bacteria Densities in Water}

During the sampling period, the whole-body-contact recreation standard $(200 \mathrm{col} / 100 \mathrm{~mL})$ - applicable from April 1 through October 31 during base-flow conditions on the main stem of the Jacks Fork - was exceeded at one or more sites on three sampling occasions. The standard was exceeded at sites 80 and 110 on August 6, 2003 (780 and $350 \mathrm{col} / 100 \mathrm{~mL}$ of sample); at site 110 on October 8, 2003 ( $320 \mathrm{col} / 100 \mathrm{~mL}$ of sample); and at sites 110 and 150 on August 11, 2004 (210 and 220 $\mathrm{col} / 100 \mathrm{~mL}$ of sample) (fig. 9). Each of these exceedences occurred in samples collected when trail rides occurred (table 2); however, the fecal coliform density of $780 \mathrm{col} / 100 \mathrm{~mL}$ at site 80 on August 6, 2003, may have been affected by effluent from the Eminence WWTP. The fecal coliform density was 7,300 $\mathrm{col} / 100 \mathrm{~mL}$ in a sample collected on the same day from the Eminence WWTP. Values above the standard also were measured in samples collected on June 10 and 11, 2003 (not included in fig. 9), at sites 80,110,150, and $165[300,>$ (greater than) 600 , $>240$, and $>240 \mathrm{col} / 100 \mathrm{~mL}$ of sample), but these probably occurred primarily as a result of runoff during wet-weather flow when the standard did not apply (fig. 4). The whole-body-contact recreation standard was not exceeded on weekdays or weekends when there was no trail ride (fig. 9).

The distribution of fecal coliform bacteria densities at seven main-stem sites, two tributary sites, and the Eminence WWTP is shown in figure 10A. The only statistically significant difference (Kruskal-Wallis Test Statistic $=17.531 ; \mathrm{p}$-value $=0.014)$ between the distributions of the seven main-stem sites was at site 80 (Jacks Fork Campground), which had significantly larger fecal coliform bacteria densities than site 5 and Alley Spring (site 15). Shawnee Creek (site 160), the tributary sampled during Phase III, generally had larger fecal coliform densities than the main-stem sites. The Eminence WWTP effluent generally was not a contributor to the fecal coliform bacteria densities in the Jacks Fork main stem. Out of 11 samples collected from the Eminence WWTP (site 70), eight had five or fewer colonies of fecal coliform bacteria per $100 \mathrm{~mL}$ of sample, and two had densities of greater than 60 and $110 \mathrm{col} / 100 \mathrm{~mL}$ of sample. The exception was the sample collected on August 6, 2003 , when the fecal coliform density was $7,300 \mathrm{col} / 100 \mathrm{~mL}$ of sample. The Eminence WWTP may have contributed to the large fecal coliform density observed on the same day downstream at site $80(780 \mathrm{col} / 100 \mathrm{~mL}$; fig. 3$)$.

Boaters and swimmers were observed on the Jacks Fork during most sample collection times in June, July, and August 2003 and 2004, including during trail rides. However, most boaters and swimmers use the Jacks Fork on the weekend. To compare the effects of intense trail-ride activity and large volumes of boaters and swimmers on fecal indicator bacteria densities, hourly sampling for fecal coliform and $E$. coli bacteria was done at site 110 on selected dates on weekends when no trail rides were taking place and on weekdays when trail rides occurred (fig. 11). Site 110 has a large gravel bar where boaters and swimmers tend to stop, picnic, and oftentimes swim. Site 110 also is an intensely used trail-ride crossing outside of the ONSR boundary (fig. 3). Starting at approximately 8:00 a.m., samples for fecal indicator bacteria analysis were collected; additional samples were collected hourly until approximately 5:00 p.m. for a total of 10 samples. During the weekend sampling, the number of canoes, kayaks, and tubes passing site 110 was recorded hourly. Likewise, during the weekday trail-ride sampling, the number of horses crossing at the site was recorded hourly. Plots of the hourly fecal coliform densities in relation to the number of canoes, kayaks, and tubes or the number of horses crossing the Jacks Fork are shown in figure 11. Generally, the fecal coliform bacteria densities tended to decrease or stay somewhat constant as the number of canoes, kayaks, and tubes passing site 110 increased (Spearman's rho correlation coefficients ranged from -0.20 to -0.80 ; fig. 11). During the hourly sampling done on August 5, 2003, fecal coliform bacteria densities tended to increase throughout the day (with peaks of 720 and 1,200 col/100 mL) in samples collected at 11:00 a.m. and 4:00 p.m., even though the number of horses crossing the 

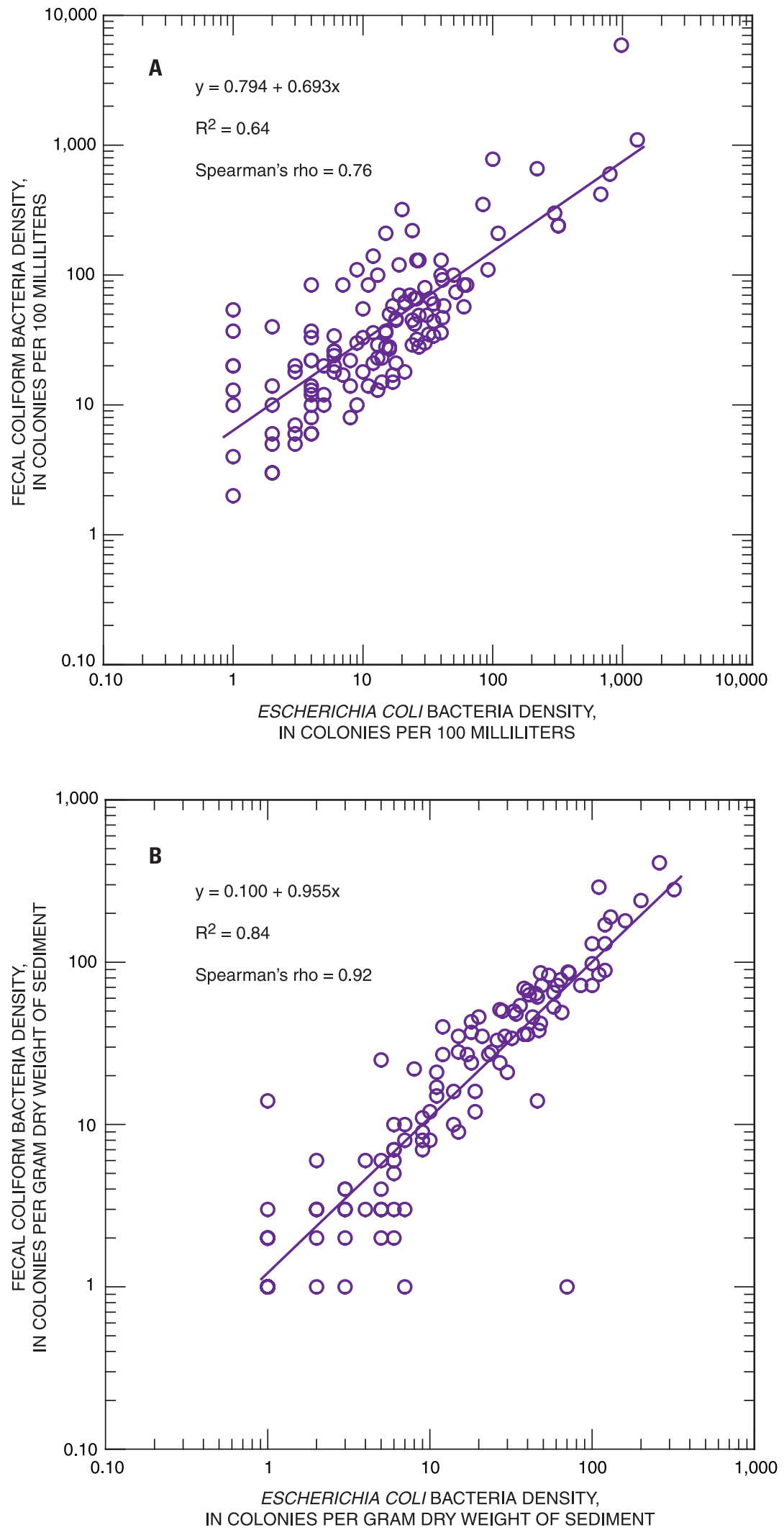

Figure 8. Relation between fecal coliform bacteria density to Escherichia colibacteria in (A) water column and (B) streambed sediment. 


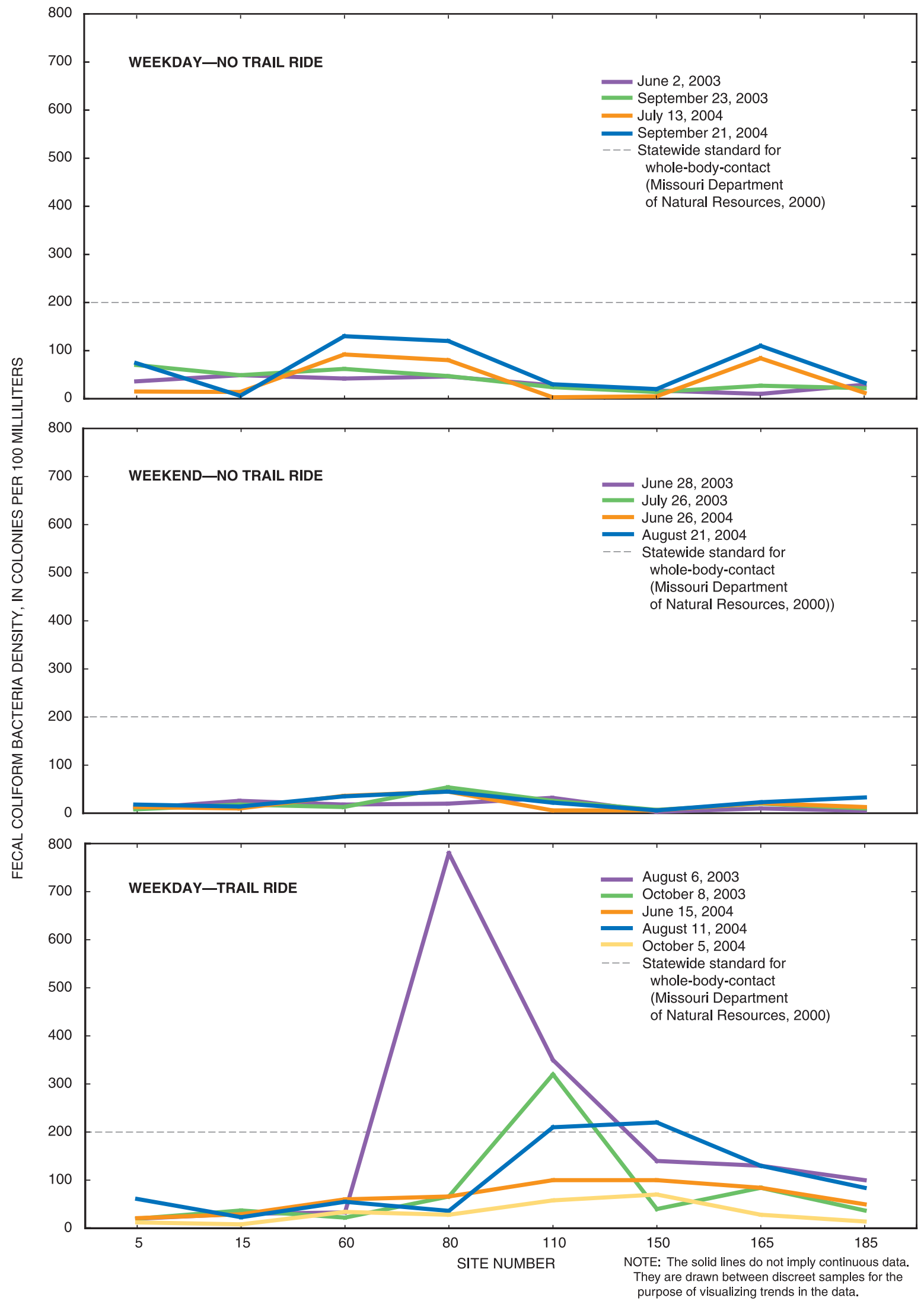

Figure 9. Fecal coliform bacteria density at selected Jacks Fork main-stem sites and Alley Spring, June 2003 through October 2004 

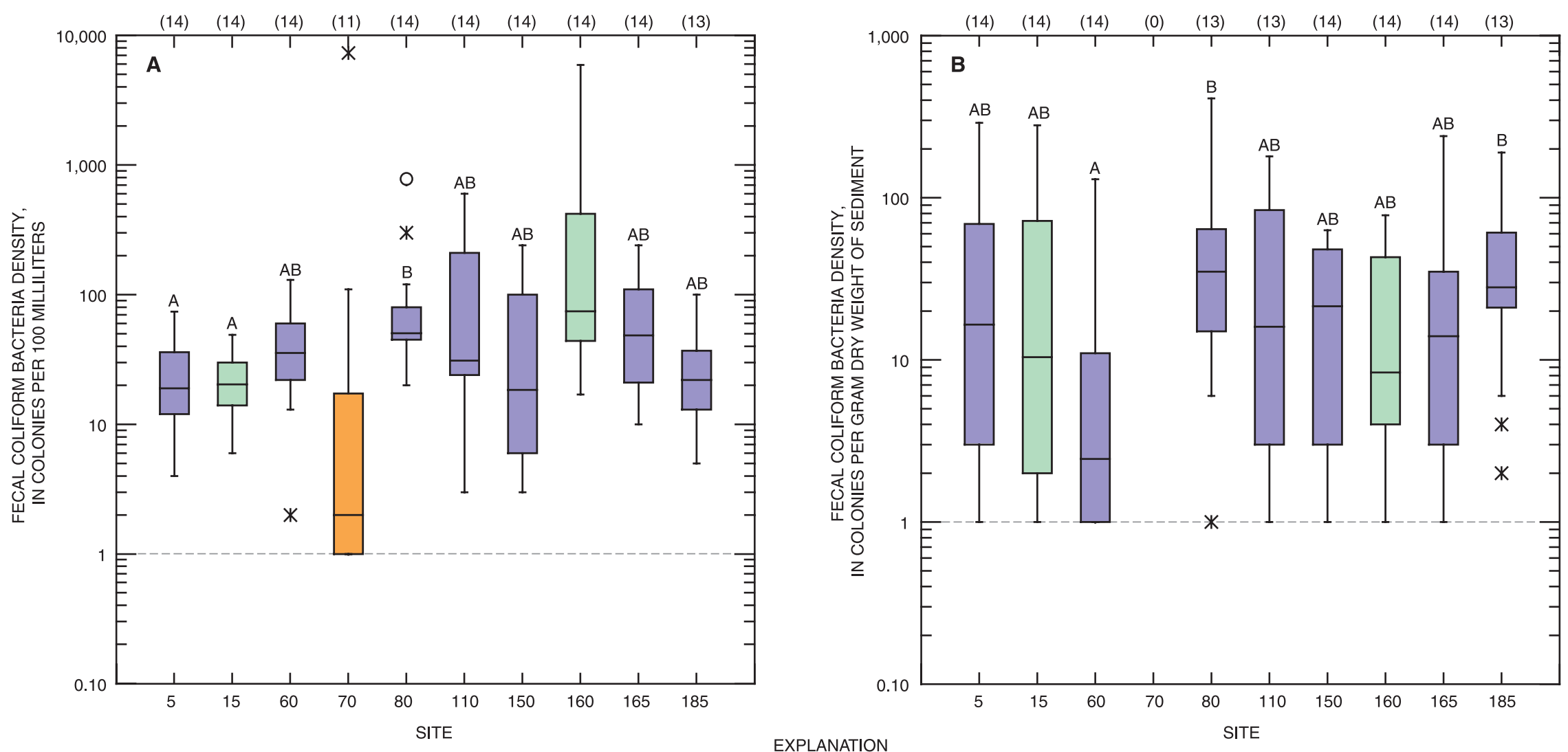

MAIN-STEM SITE

TRIBUTARY SITE

EMINENCE WASTEWATER TREATMENT PLANT

A LETTER-Distributions associated with the same letter are not significantly ( $p$ value less than 0.05 ) different. The absence of a letter indicates that $n$ statistically significant differences exist. Comparisons are between main stem sites and Alley Spring (site 15)

EXPLANATION

Figure 10. Fecal coliform bacteria density in (A) water column and (B) streambed sediment at main-stem and tributary sites and the Eminence Wastewater Treatment Plant on the Jacks Fork, June 2003 through October 2004. 

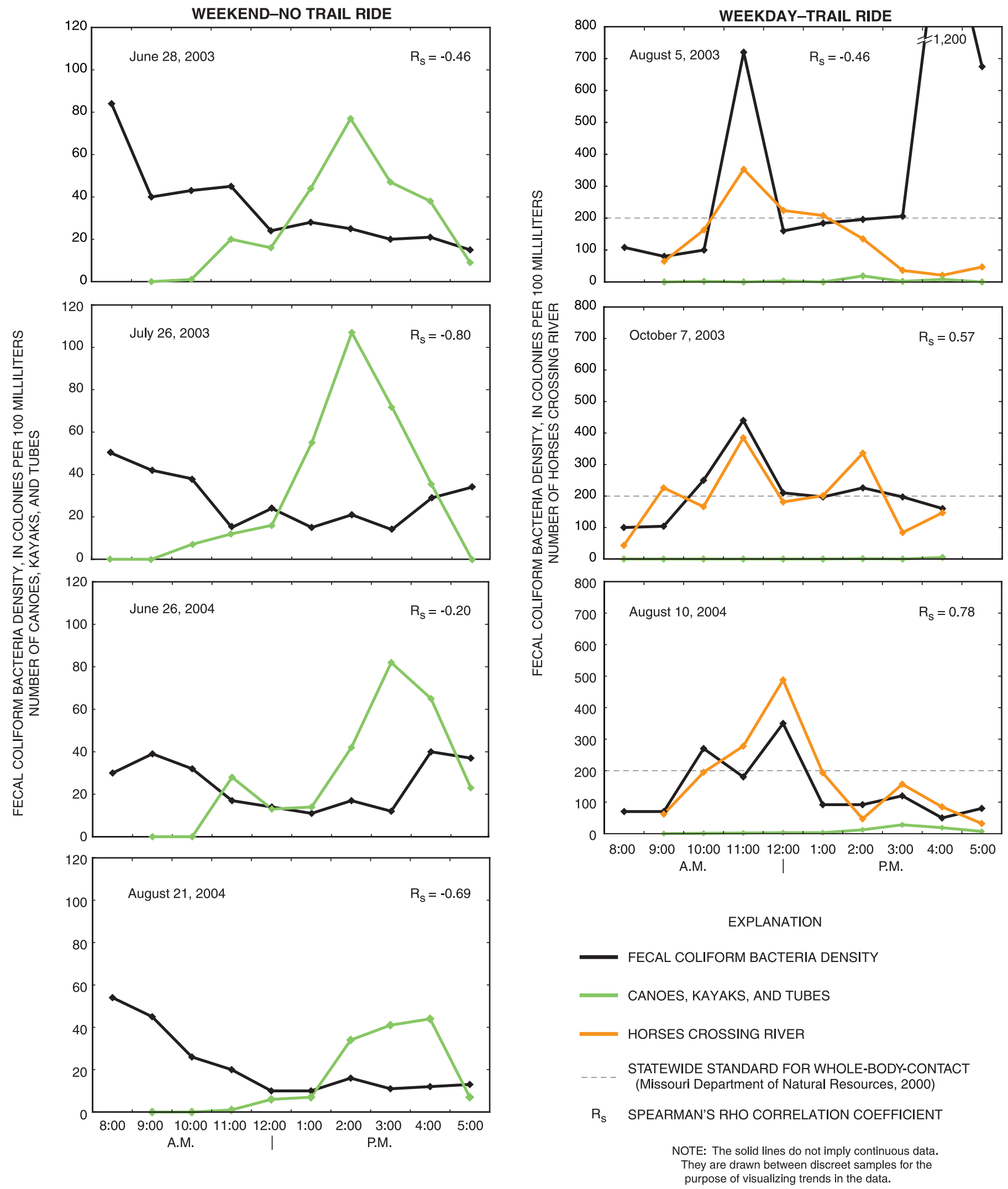

Figure 11. Fecal coliform bacteria density at site 110 during selected weekends and trail rides. 
Jacks Fork decreased substantially in the afternoon (Spearman's rho correlation coefficient was -0.46; fig. 11). During the hourly sampling done on October 7, 2003, and August 10, 2004, the fecal coliform densities tended to increase as the number of horses crossing the river increased, and decrease with a decrease in the number of horses crossing the river (Spearman's rho correlation coefficients were 0.57 and 0.78 , respectively; fig. 11).

\section{Fecal Indicator Bacteria Densities in Streambed Sediment}

Because bacteria can survive longer in streambed sediments than in water, a source of bacteria in the water column could be from resuspension of accumulated bacteria from streambed sediments (Marino and Gannon, 1991). The fecal bacteria stored in the streambed sediments may be returned to the water column by physical disturbance of the streambed sediments by processes such as dredging (Grimes, 1980), by wind and wave action (Lehman and Fogel, 1976), and by boaters or swimmers (Bromel and others, 1978). In the case of the Jacks Fork, the mechanical action could be caused by the movement of horses (up to 500 horses crossing per hour at site 110; fig. 11) through the water or by boaters and swimmers (up to 110 recreational boats and tubes passing per hour at site 110; fig. 11). Streambed-sediment samples were collected at all Jacks Fork main-stem and tributary sites and analyzed for fecal coliform and $E$. coli concurrent with water samples.

The distribution of fecal coliform bacteria densities in streambed sediments at seven main-stem sites and two tributary sites is shown in figure 10B. The only statistically significant differences (Kruskal-Wallis Test Statistic $=12.430$; $\mathrm{p}$-value $=$ 0.047 ) between the distributions of the seven main-stem sites and Alley Spring were at sites 80 and 185, which had significantly larger fecal coliform bacteria densities than site 60. Comparisons of fecal coliform densities in water column and streambed sediment for each sample collected are shown in figure 12. No particular relation is apparent between the fecal coliform densities in water and streambed sediment on examination of these graphical representations of the data. However, the largest fecal coliform densities in the water column and streambed sediment generally occurred during trail rides (fig. 12). For comparison, streambed-sediment and water-column samples collected at site 110 during Phase II of the study before and during a trail ride in August 2000 indicated that the fecal-bacteria densities increased in the streambed sediment and water column during the trail ride (Davis and Richards, 2002). The data set considered during Phase II was limited in size and scope, however, and perhaps was not representative of conditions during various recreational activities over a longer period of time.

To characterize the streambed-sediment quality at each site and aid in data interpretation, particle-size analysis was determined on selected streambed-sediment samples (table 3; fig. 13). The streambed sediments from the main-stem sites were composed primarily of gravel and sand-size particles, with the percentage of sand-size sediments 63 to 2,000 $\mu \mathrm{m}$, ranging from an average of 44 percent at site 165 to an average of 68 percent at site 5 . Silt- and clay-size particles $(<63 \mu \mathrm{m})$ generally accounted for less than 5 percent of the total streambed sediment at these same sites. A notable exception is site 60 , where a maximum of 34 percent and an average of 8.2 percent of the streambed sediments were composed of silt- and clay-size particles. A clay lens is located on the right edge of the water at site 60 . When one of the three streambed-sediment samples were collected from this clay lens, the percentage of silt- and claysize particles increased as in the samples collected on June 26 and August 11, 2004. A similar clay lens is located on the left edge of the water at site 150 , but only the sample collected on August 11, 2004 (20 percent silt and clay) contained a subsample from this lens. Despite the higher fraction of small particles in these three samples, no increased detection of fecal indicator bacteria was observed. This could be caused, in part, by the 10hour settling time, during which some of the particle-bound and aggregated fecal coliform bacteria may have fallen out of suspension. Streambed sediments at site 15 (Alley Spring) were composed predominantly of sand-size particles, with an average composition of 86 percent sand.

The relations of fecal coliform densities in streambed sediment to the fecal coliform densities in the water column and to particle size were considered. The results of these analyses are presented in figure 14. The relation of fecal coliform density in the water column to fecal coliform density in streambed sediment had a small positive correlation (Spearman correlation coefficient of 0.18 ), with fecal coliform densities in streambed sediment accounting for only about 4 percent of the variation in the fecal coliform bacteria densities in the water column (multiple $\mathrm{R}^{2}$ of 0.04 ) (fig. 14A). The relation of fecal coliform density in streambed sediment to sediment particle size of less than $2,000 \mu \mathrm{m}$ (sand, silt, and clay size) had a positive correlation (Spearman correlation coefficient of 0.42), with particle size of less than 2,000 $\mu \mathrm{m}$ accounting for about 19 percent of the variation in the fecal coliform bacteria densities in streambed sediments (multiple $\mathrm{R}^{2}$ of 0.19) (fig. 14B). The relation of fecal coliform density in streambed sediment to sediment particle size of less than $63 \mu \mathrm{m}$ (silt and clay size) was not statistically significant ( $\mathrm{p}$-value of less than 0.05). This may indicate a hydromorphological effect, in that velocities that scour fine sediments also reduce deposition of fecal indicator bacteria.

It is apparent from the fecal coliform in streambed-sediment data (figs. 10 and 12) that storage of fecal coliform bacteria in streambed sediments occurs, but the factors that affect the storage and release of these bacteria have not been determined. The results of this study indicate that the presence of large densities of fecal bacteria in the water column during some trail rides cannot always be explained by storage and subsequent resuspension of fecal indicator bacteria in the Jacks Fork. This conclusion is supported by the observation that fecal coliform bacteria densities in the streambed sediments often were small when the densities were large in the water column. Conversely, the densities of fecal coliform bacteria often were small in the 


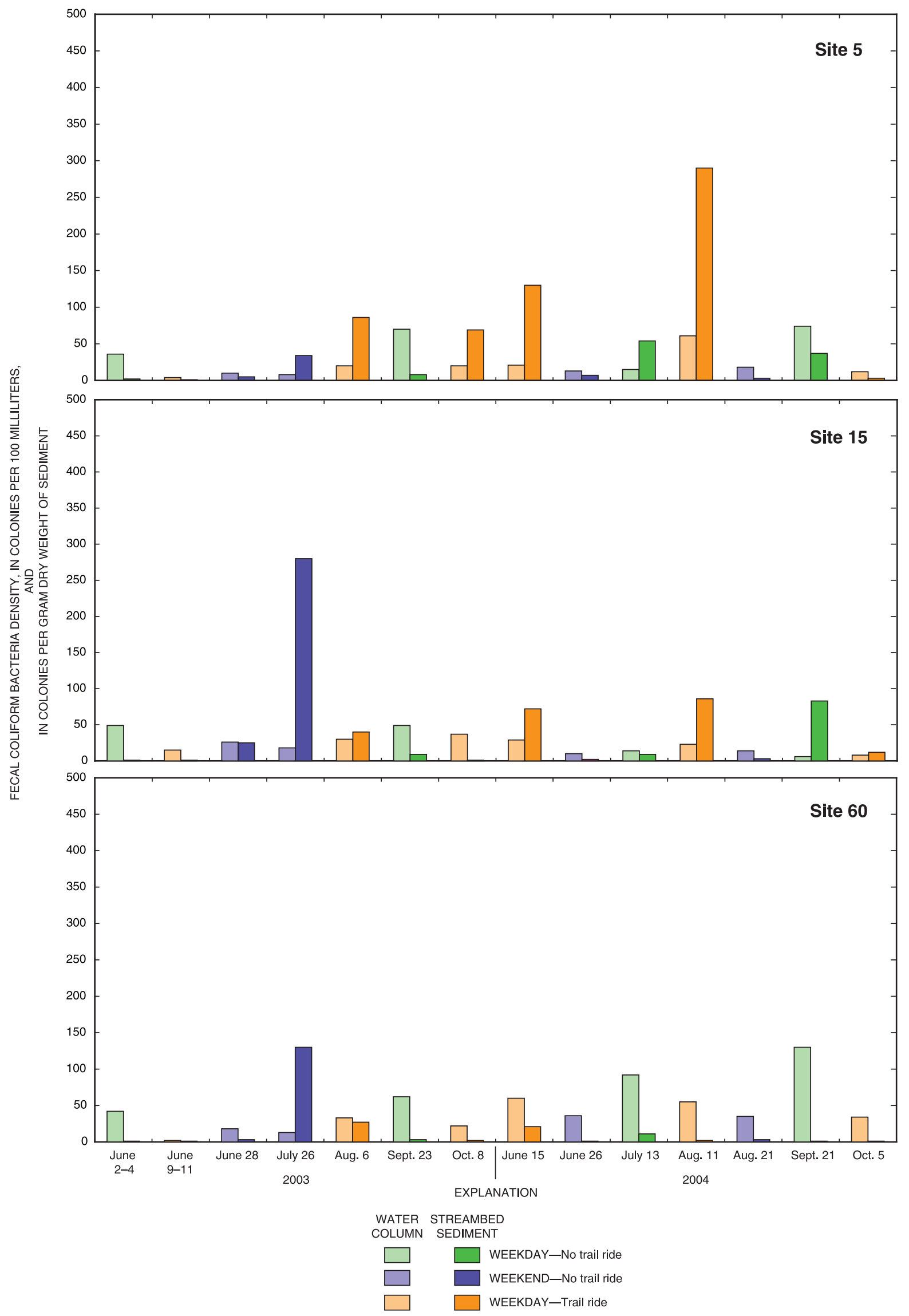

Figure 12. Fecal coliform bacteria density in water column and streambed sediment at Jacks Fork main-stem sites and Alley Spring, June 2003 through October 2004. 


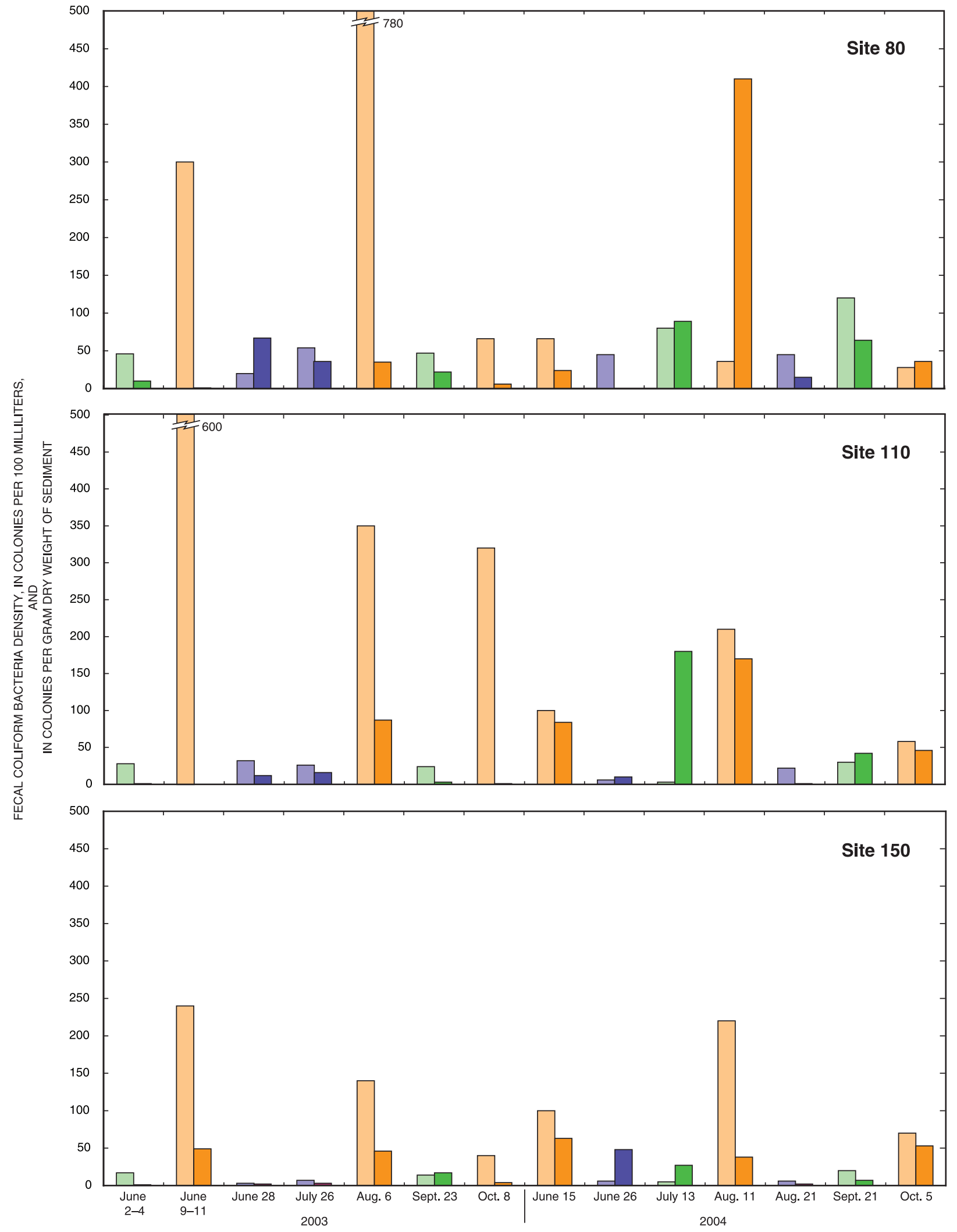

Figure 12. Fecal coliform bacteria density in water column and streambed sediment at Jacks Fork main-stem sites and Alley Spring, June 2003 through October 2004.-Continued 

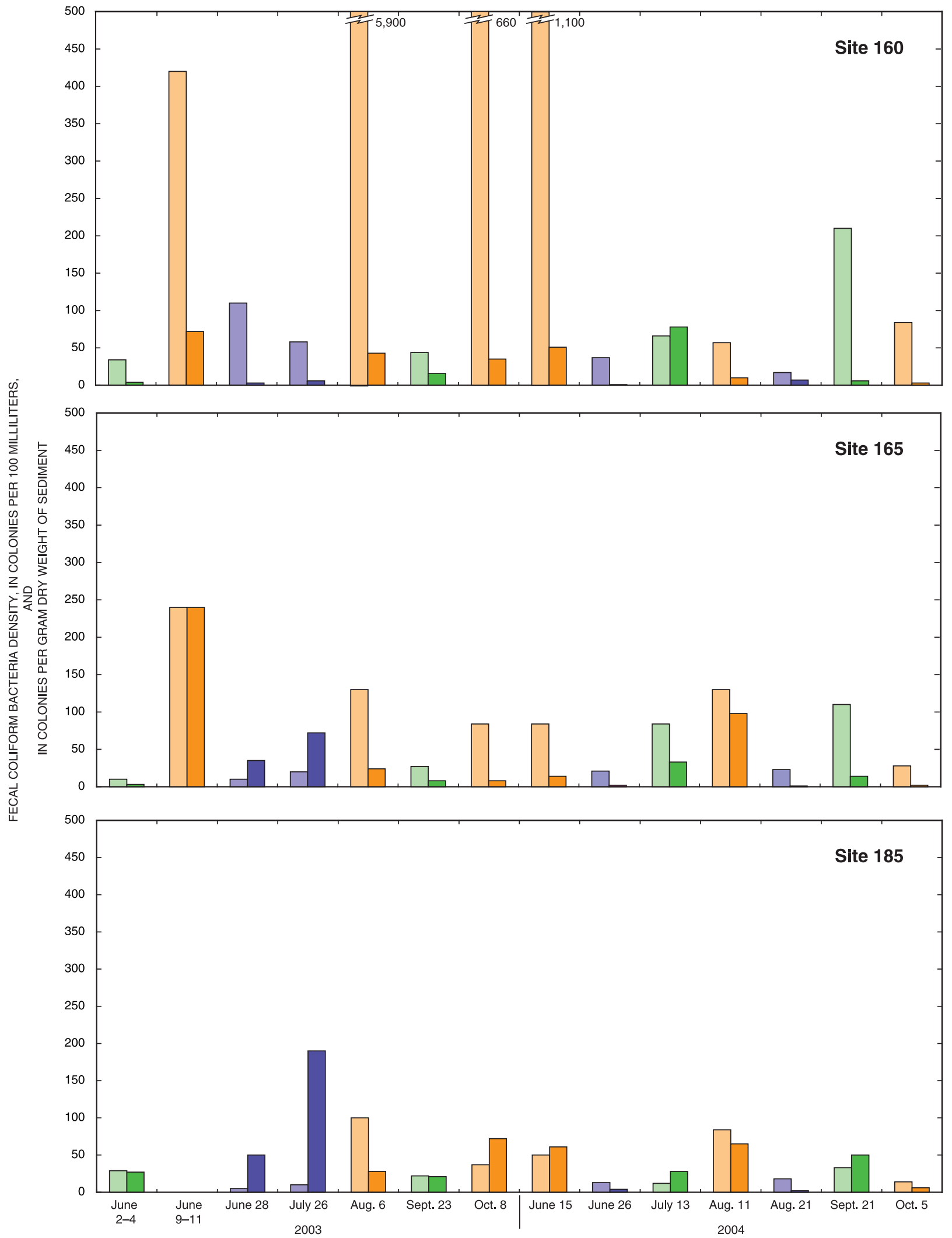

Figure 12. Fecal coliform bacteria density in water column and streambed sediment at Jacks Fork main-stem sites and Alley Spring, June 2003 through October 2004.-Continued 
Table 3. Particle-size analysis of streambed sediments.

[g, grams; $\mu \mathrm{m}$, micrometer; --, not applicable]

\begin{tabular}{|c|c|c|c|c|}
\hline \multirow[b]{2}{*}{ Date } & \multirow[b]{2}{*}{ Total sediment dry weight (g) } & \multicolumn{3}{|c|}{ Percent finer than $(\mu \mathrm{m})$} \\
\hline & & 2,000 & 250 & 63 \\
\hline \multicolumn{5}{|c|}{ Jacks Fork above Alley Spring (site 5, fig.3) } \\
\hline $7-26-2003$ & 19.2 & 100 & -- & 0.2 \\
\hline $8-06-2003$ & 15.1 & 100 & -- & .2 \\
\hline $9-23-2003$ & 10.7 & 38 & 0.4 & .2 \\
\hline $6-26-2004$ & 13.5 & 44 & -- & .4 \\
\hline 8-11-2004 & 18.1 & 59 & -- & 10 \\
\hline $10-05-2004$ & 8.9 & 66 & -- & .7 \\
\hline \multicolumn{5}{|c|}{ Alley Spring below Alley (site 15, fig. 3) } \\
\hline $7-26-2003$ & 11.2 & 92 & 18 & 1.6 \\
\hline 8-06-2003 & 4.7 & 97 & 26 & 7.2 \\
\hline $9-23-2003$ & 9.9 & 72 & 15 & 1.0 \\
\hline $6-26-2004$ & 10.8 & 73 & -- & .4 \\
\hline 8-11-2004 & 11.8 & 86 & -- & 16 \\
\hline $10-05-2004$ & 6.3 & 97 & -- & 2.5 \\
\hline \multicolumn{5}{|c|}{ Jacks Fork at Eminence (site 60, fig. 3) } \\
\hline $7-26-2003$ & 10.1 & 62 & 6.2 & 1.1 \\
\hline 8-06-2003 & 15.7 & 43 & 2.1 & .5 \\
\hline $9-23-2003$ & 10.6 & 73 & 7.3 & .5 \\
\hline $6-26-2004$ & 6.1 & 57 & -- & 34 \\
\hline 8-11-2004 & 22.6 & 46 & -- & 9.1 \\
\hline $10-05-2004$ & 9.3 & 29 & -- & 3.6 \\
\hline \multicolumn{5}{|c|}{ Jacks Fork above $2^{\text {nd }}$ unnamed hollow below Eminence (site 80, fig. 3) } \\
\hline $7-26-2003$ & 10.9 & 57 & 9.5 & 0.8 \\
\hline $8-06-2003$ & 17.6 & 38 & 1.6 & .3 \\
\hline $9-23-2003$ & 16.0 & 58 & 5.8 & 6 \\
\hline $8-11-2004$ & 15.5 & 70 & -- & 12 \\
\hline $10-05-2004$ & 10.8 & 49 & -- & .3 \\
\hline \multicolumn{5}{|c|}{ Jacks Fork above Lick Log Hollow below Eminence (site 110, fig. 3) } \\
\hline $7-26-2003$ & 12.9 & 53 & 9.1 & 2.9 \\
\hline $8-06-2003$ & 14.8 & 56 & 4.2 & .8 \\
\hline $9-23-2003$ & 14.9 & 46 & 2.2 & .5 \\
\hline 6-26-2004 & 13.7 & 67 & -- & 1.7 \\
\hline 8-11-2004 & 12.1 & 87 & -- & 14 \\
\hline $10-05-2004$ & 6.2 & 94 & -- & 2.4 \\
\hline
\end{tabular}


Table 3. Particle-size analysis of streambed sediments.-Continued

[g, grams; $\mu \mathrm{m}$, micrometer; --, not applicable]

\begin{tabular}{|c|c|c|c|c|}
\hline \multirow[b]{2}{*}{ Date } & \multirow[b]{2}{*}{ Total sediment dry weight $(\mathrm{g})$} & \multicolumn{3}{|c|}{ Percent finer than $(\mu \mathrm{m})$} \\
\hline & & 2,000 & 250 & 63 \\
\hline \multicolumn{5}{|c|}{ Jacks Fork above Powell Spring above Two Rivers (site 150, fig. 3) } \\
\hline $7-26-2003$ & 54.2 & 8. & 1.7 & 0.1 \\
\hline $8-06-2003$ & 15.8 & 36 & 7.8 & 1.2 \\
\hline $9-23-2003$ & 14.0 & 66 & 8.6 & 1.8 \\
\hline $6-26-2004$ & 16.4 & 40 & -- & .5 \\
\hline $8-11-2004$ & 20.4 & 54 & -- & 20 \\
\hline $10-05-2004$ & 6.3 & 67 & -- & 3.4 \\
\hline \multicolumn{5}{|c|}{ Shawnee Creek above Two Rivers (site 160, fig. 3) } \\
\hline $7-26-2003$ & 48.9 & 18 & 2.5 & 1.6 \\
\hline $8-06-2003$ & 8.8 & 36 & 3.3 & 1.5 \\
\hline $9-23-2003$ & 18.8 & 29 & 4.6 & 3.4 \\
\hline $6-26-2004$ & 13.5 & 16 & -- & 7.2 \\
\hline $8-11-2004$ & 22.7 & 52 & -- & 9.3 \\
\hline $10-05-2004$ & 11.4 & 43 & -- & 1.0 \\
\hline \multicolumn{5}{|c|}{ Jacks Fork above Little Shawnee Creek above Two Rivers (site 165, fig. 3) } \\
\hline $7-26-2003$ & 11.3 & 55 & 4.5 & 0.9 \\
\hline $8-06-2003$ & 10.4 & 35 & 2.4 & .4 \\
\hline $9-23-2003$ & 19.7 & 46 & 3.0 & .6 \\
\hline $6-26-2004$ & 18.5 & 36 & -- & 5.1 \\
\hline 8-11-2004 & 18.8 & 53 & -- & 9.9 \\
\hline $10-05-2004$ & 18.0 & 41 & -- & 1.7 \\
\hline \multicolumn{5}{|c|}{ Jacks Fork below 3rd unnamed hollow above Two Rivers (site 185, fig. 3) } \\
\hline $7-26-2003$ & 9.9 & 53 & 12.8 & 1.2 \\
\hline $8-06-2003$ & 11.8 & 47 & 12.7 & .8 \\
\hline $9-23-2003$ & 16.8 & 78 & 15.8 & 2.4 \\
\hline $6-26-2004$ & 14.3 & 51 & -- & 1.1 \\
\hline $8-11-2004$ & 16.8 & 65 & -- & 11 \\
\hline $10-05-2004$ & 7.4 & 51 & -- & .4 \\
\hline
\end{tabular}

water column when the densities were large in the streambed sediment (fig. 12).

The inconclusiveness of the results may be attributed, in part, to the study design. During the 10-hour settling time, some of the particle-bound and aggregated fecal coliform and E. coli bacteria may have fallen out of suspension. The resulting densities are likely underestimates of the bacteria present in the streambed sediment, and the part of the bacteria successfully cultivated from the streambed sediment by this procedure is dependent, partially, on the particle-size distribution in the streambed sediment. The bacteria that were detected after the 10- hour settling time are bacteria that did not attach to particles, or that are easily disassociated from particles.

\section{Microbial Source Tracking}

During Phase II of this study, the MST technique known as ribotyping was used to identify presumptive sources of fecal bacteria in the Jacks Fork (Davis and Richards, 2002; Carson and others, 2001). Sixty-five $E$. coli isolates from water samples collected at 9 sites and $23 \mathrm{E}$. coli isolates obtained from streambed-sediment samples collected at 5 sites during a variety of nonrecreational and recreational season river uses were submit- 


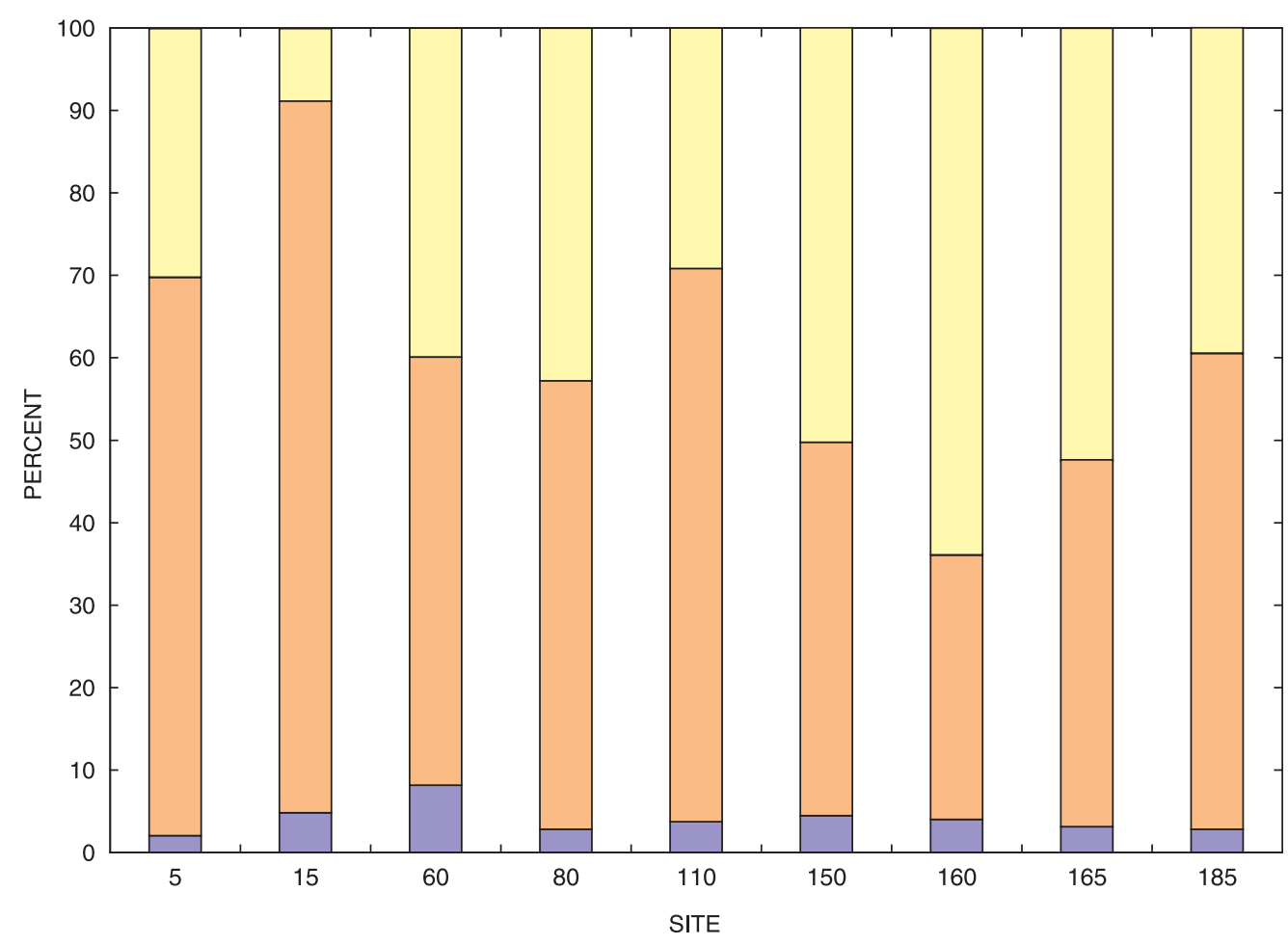

EXPLANATION

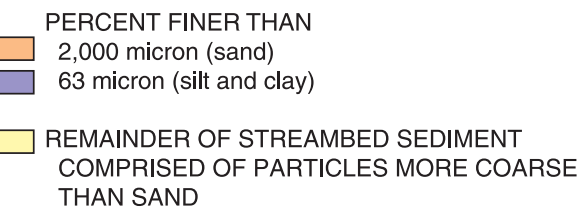

Figure 13. Percentage of sand compared to silt and clay in streambed-sediment samples.

ted for ribotyping analysis. Ribotypes were compared to a library of ribotypes from three known sources: sewage, horses, and cattle. Of the 65 isolates from water samples, 40 percent were identified as originating from sewage, 29 percent from horse, 11 percent from cow, and 20 percent from unknown sources. Of the 23 isolates from streambed-sediment samples, 39 percent were identified as originating from sewage, 35 percent from horse, 13 percent from cow, and 13 percent from unknown sources. The overall results indicated that the predominant sources of E. coli bacteria were sewage and horses. However, these ribotyping results were considered experimental for the purpose of the Phase II study because the method was under development.

During Phase III of the study, rep-PCR was the method chosen for differentiating between possible sources of $E$. coli. Results of a study comparing the ribotyping and rep-PCR methods indicated that rep-PCR was more accurate, reproducible, and efficient in associating DNA fingerprints of E. coli with human and animal hosts of origin (Carson and others, 2003).

Isolates of $E$. coli for rep-PCR analysis were obtained from water samples collected at five sites $(80,110,150,160$, and
165 ) in the 303(d) reach of the Jacks Fork (fig. 3; table 1). All samples were collected when trail rides occurred, with the exception of one set of samples collected in the early part of the recreational season, June 2 to 4, 2003. This decision was based largely on the fact that since the study began in 1999, the wholebody-contact recreation standard was exceeded only during trail rides (Davis and Richards, 2001, 2002); therefore, the presumptive identification of sources of fecal bacteria in the Jacks Fork during trail rides was given priority. Results of the rep-PCR analysis are presented in table 4. A total of $501 E$. coli isolates were analyzed; 70 isolates were assigned to sewage, 118 to cattle, 132 to horses, and 181 unknown. The RCC, as determined by cross-validation, were 85 percent for sewage, 88 percent for horses, and 94 percent for cattle. The presumptive source of a large number of isolates could not be identified. The inability to assign these isolates to a particular source could be because the source is not sewage, horse, or cattle; or because the knownhost source horse library, which is composed of samples from horses from multiple places outside of the Jacks Fork Basin, may not be representative of the horses present during trail rides when samples were collected for rep-PCR analysis. 

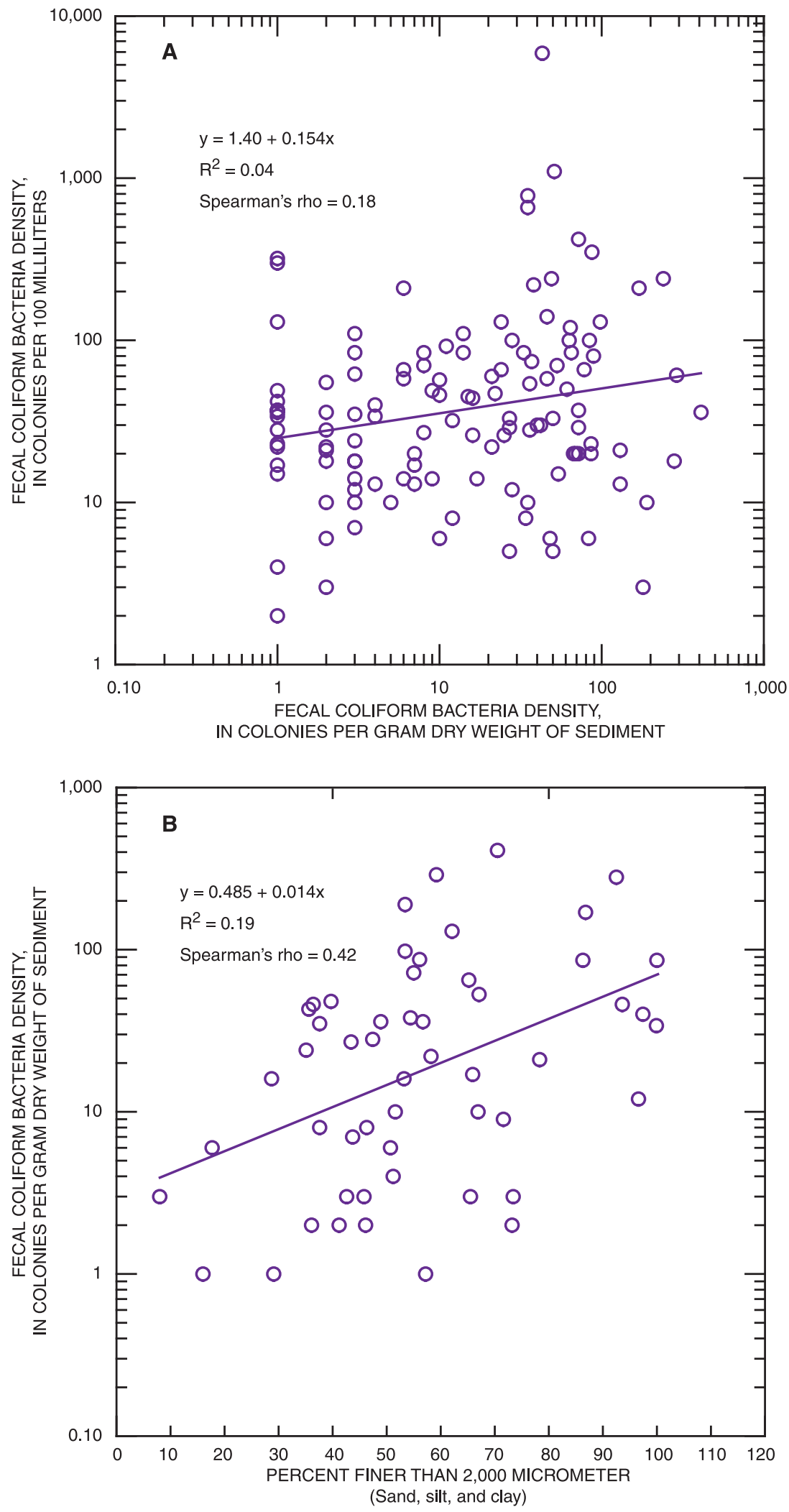

Figure 14. Relations of fecal coliform bacteria density in streambed sediment to (A) fecal coliform bacteria density in water column and (B) particle size. 
Table 4. Number of Escherichia coli isolates in water-column samples assigned to various sources by repetitive polymerase chain reaction.

[col/100 mL, colonies per 100 milliliters of sample; col/g, colonies per gram of sample; E. coli, Escherichia coli; <, less than; >, greater than; ,-- no data available]

\begin{tabular}{|c|c|c|c|c|c|c|c|}
\hline \multirow{2}{*}{$\begin{array}{c}\text { Site } \\
\text { number } \\
\text { (fig. 7) }\end{array}$} & \multirow{2}{*}{$\begin{array}{c}\text { E. coli } \\
(\mathrm{col} / 100 \mathrm{~mL})^{\mathrm{a}}\end{array}$} & \multirow{2}{*}{$\begin{array}{c}\text { Total } \\
\text { number of } \\
\text { isolates }^{b}\end{array}$} & \multirow{2}{*}{$\begin{array}{l}\text { Percent } \\
\text { identified }\end{array}$} & \multicolumn{4}{|c|}{$\begin{array}{c}\text { Possible source } \\
\text { (probability of } 0.80 \text { or larger) }\end{array}$} \\
\hline & & & & Sewage & Horse & Cattle & Unknown \\
\hline \multicolumn{8}{|c|}{ June 2 to 4,2003} \\
\hline 80 & 18 & 15 & 53 & 2 & 5 & 1 & 7 \\
\hline 110 & 15 & 16 & 44 & 2 & 2 & 3 & 9 \\
\hline 150 & 7 & 17 & 82 & 2 & 9 & 3 & 3 \\
\hline 160 & 6 & 4 & 50 & 1 & 0 & 1 & 2 \\
\hline 165 & 5 & 4 & 75 & 2 & 1 & 0 & 1 \\
\hline \multicolumn{8}{|c|}{ June 9 to 10, 2003} \\
\hline 80 & 300 & 10 & 60 & 1 & 1 & 4 & 4 \\
\hline 110 & $>800$ & 12 & 50 & 2 & 3 & 1 & 6 \\
\hline 150 & $>320$ & 17 & 53 & 2 & 3 & 4 & 8 \\
\hline 160 & 680 & 19 & 74 & 5 & 2 & 7 & 5 \\
\hline 165 & $>320$ & 10 & 70 & 0 & 4 & 3 & 3 \\
\hline \multicolumn{8}{|c|}{ August 6, 2003} \\
\hline 80 & 100 & 18 & 78 & 7 & 2 & 5 & 4 \\
\hline 110 & 84 & 19 & 47 & 0 & 5 & 4 & 10 \\
\hline 150 & 12 & 10 & 30 & 0 & 2 & 1 & 7 \\
\hline 160 & 980 & -- & -- & -- & -- & -- & -- \\
\hline 165 & 27 & 19 & 47 & 1 & 3 & 5 & 10 \\
\hline \multicolumn{8}{|c|}{ October 8, 2003} \\
\hline 80 & 26 & 11 & 73 & 1 & 3 & 4 & 3 \\
\hline 110 & 20 & 15 & 80 & 0 & 9 & 3 & 3 \\
\hline 150 & $<2$ & 17 & 59 & 3 & 6 & 1 & 7 \\
\hline 160 & 220 & 11 & 64 & 2 & 1 & 4 & 4 \\
\hline 165 & 4 & 14 & 71 & 3 & 3 & 4 & 4 \\
\hline \multicolumn{8}{|c|}{ June 15, 2004} \\
\hline 80 & 33 & 13 & 69 & 3 & 3 & 3 & 4 \\
\hline 110 & 50 & 19 & 74 & 2 & 8 & 4 & 5 \\
\hline 150 & 13 & 20 & 65 & 4 & 5 & 4 & 7 \\
\hline 160 & 1,300 & 20 & 70 & 2 & 7 & 5 & 6 \\
\hline 165 & 60 & 20 & 100 & 2 & 14 & 4 & 0 \\
\hline \multicolumn{8}{|c|}{ August 11, 2004} \\
\hline 80 & 40 & 16 & 25 & 2 & 0 & 2 & 12 \\
\hline 110 & 110 & 20 & 70 & 2 & 8 & 4 & 6 \\
\hline 150 & 24 & 20 & 60 & 3 & 6 & 3 & 8 \\
\hline 160 & 60 & 17 & 47 & 2 & 2 & 4 & 9 \\
\hline 165 & 40 & 20 & 45 & 1 & 5 & 3 & 11 \\
\hline \multicolumn{8}{|c|}{ October 5, 2004} \\
\hline 80 & 27 & 2 & 100 & 0 & 0 & 2 & 0 \\
\hline 110 & 42 & 18 & 89 & 2 & 3 & 11 & 2 \\
\hline 150 & 19 & 12 & 67 & 0 & 0 & 8 & 4 \\
\hline 160 & 63 & 17 & 82 & 6 & 7 & 1 & 3 \\
\hline 165 & 16 & 9 & 56 & 3 & 0 & 2 & 4 \\
\hline
\end{tabular}

${ }^{\text {a }}$ Samples collected and processed by the U.S. Geological Survey.

${ }^{\mathrm{b}}$ Samples collected by the U.S. Geological Survey and processed by the University of Missouri in Columbia, Missouri, College of Veterinary Medicine. 


\section{Assessment of Possible Sources of Microbiological Contamination of the Jack Forks-Phase III}

Horses were the predominant source identified (17 isolates) in samples collected during the early part of the recreational season June 2 to 4, 2003. Cattle were the predominant source identified (19 isolates) June 9 to 11, 2003, when trail rides occurred, which is not unexpected because of rainfall and subsequent runoff that occurred during sample collection. Cattle graze on bottomland pastures in the Jacks Fork Basin, and runoff from these pastures could contribute to fecal bacteria levels in the water column and streambed sediment in the Jacks Fork. As stated previously, the whole-body-contact standard did not apply during wet-weather flow. Isolates identified as originating from cattle predominated in samples collected when trail rides occurred August 6, 2003 (15 isolates from cattle; 12 from horses), and October 5, 2004 (24 isolates from cattle; 10 from horses). Isolates identified as originating from horses predominated in samples collected when trail rides occurred October 8, 2003 (22 isolates from horses; 16 from cattle); June 15, 2004 (37 isolates from horses; 20 from cattle); and August 11, 2004 (21 isolates from horses; 16 from cattle). With respect to presumptive source identification at individual sites, cattle were the predominant source identified at site 80 in 3 of 7 samples and at site 160 in 3 of 6 samples, and about evenly split between cattle and horses at site 165 . Horses were the predominant source identified in 5 of 7 samples collected at sites 110 and 150 , which are both located at intensely used trail-ride crossings (table 4). No cattle were observed grazing near the Jacks Fork main-stem sites and Shawnee Creek (site 160) where cattle were identified as the predominant source. A source of these bacteria could be the streambed sediments, which have been disturbed by trail-ride activity.

The 7 river-mile reach of the Jacks Fork was included on the 303(d) list because of fecal coliform bacteria densities that, on occasion, exceed the Statewide water-quality standard for whole-body-contact recreation. The rep-PCR results for the individual samples that were collected at sites that had water column fecal coliform bacteria densities of 200 or greater col/ $100 \mathrm{~mL}$ on the day of sample collection, as well as samples that had fecal coliform densities at the $75^{\text {th }}$ percentile level or greater are examined in more detail in figure 15. Rep-PCR samples collected on August 6, 2003 (whole-body-contact standard exceeded at sites 80 and 110), at sites 110 and 150 had a predominance of isolates attributed to horses; the predominant source at site 165 was cattle. Sewage was the predominant source in the sample collected at site 80 on the same day, which had a water column fecal coliform bacteria density of $780 \mathrm{col} /$ $100 \mathrm{~mL}$. The large percentage of isolates attributed to sewage in this sample probably is related to the release of effluent from the Eminence WWTP, which had a fecal coliform density of 7,300 col/100 mL on August 6, 2003. Fecal coliform densities exceeded the whole-body-contact standard at sites 110 and 160 on October 8, 2003. Rep-PCR analysis of these samples indicated that isolates identified as horse predominated at site 110, whereas isolates identified as originating from cattle predominated at site 160. In samples collected on June 15, 2004, at sites 110,150 , and 160 (whole-body-contact standard exceeded at site 160) and on August 11, 2004, at sites 110 and 150 (whole- body-contact standard exceeded at both sites), isolates identified as originating from horses predominated. As discussed previously, no cattle were observed grazing near the sites where cattle were identified as the predominant source, and, therefore, a source of these bacteria could be the streambed sediments.

\section{Summary}

In 1998, a 5 river-mile reach of the Jacks Fork was included on Missouri's list of impaired waters as required by Section 303(d) of the Federal Clean Water Act. The identified pollutant on the Jacks Fork was fecal coliform bacteria, whose presence in large numbers indicates contamination by fecal wastes of humans and other warm-blooded animals. The Statewide standard of acceptable risk for whole-body-contact recreation is $200 \mathrm{col} / 100 \mathrm{~mL}$ (colonies per 100 milliliters) of sample. Potential sources of fecal contamination to the Jacks Fork include a wastewater treatment plant, campground pit-toilet or septic-system effluent, cross-country horseback trail riding, recreational boaters and swimmers, cattle, and wildlife. The length of the impaired reach was changed to 7 miles on the Missouri 2002 303(d) list because of data indicating the fecal coliform bacteria problem existed over a broader area.

The U.S. Geological Survey, in cooperation with the National Park Service, conducted a three-phase study to better understand the extent and sources of microbiological contamination within the Jacks Fork from Alley Spring to the mouth, which includes the 7-mile 303(d) reach. Identification of the sources would provide the National Park Service and the State of Missouri with the information needed to craft a solution of abatement, regulation, prevention, and mitigation with the end result being reduction of bacterial levels and removal of the Jacks Fork from the 303(d) list.

During Phase III of the study, 10 sites were sampled from June 2003 through October 2003 and from June 2004 through October 2004. Samples were collected mostly during base-flow conditions during a variety of recreational season river uses, including boating, swimming, tubing, and horseback riding. Water-column and streambed-sediment samples were analyzed for fecal indicator bacteria [fecal coliform and Escherichia coli (E. coli)]. Sieve analysis also was performed on selected streambed-sediment samples to determine particle-size distributions at each sampling location. Water-column samples also were analyzed for physical properties and nutrients. Additional water-column samples were collected and sent to the University of Missouri, Columbia, College of Veterinary Medicine for repetitive extragenic palidromic polymerase chain reaction (rep-PCR) analysis.

During the sampling period, the whole-body-contact recreation standard was exceeded at sites 80 and 110 on August 6, 2003 ( 780 and $350 \mathrm{col} / 100 \mathrm{~mL}$ ); at site 110 on October 8, 2003 (320 col/100 mL); and at sites 110 and 150 on August 11, 2004 (210 and $220 \mathrm{col} / 100 \mathrm{~mL}$ ). Each of these exceedences occurred in samples collected when trail rides occurred. However, the 

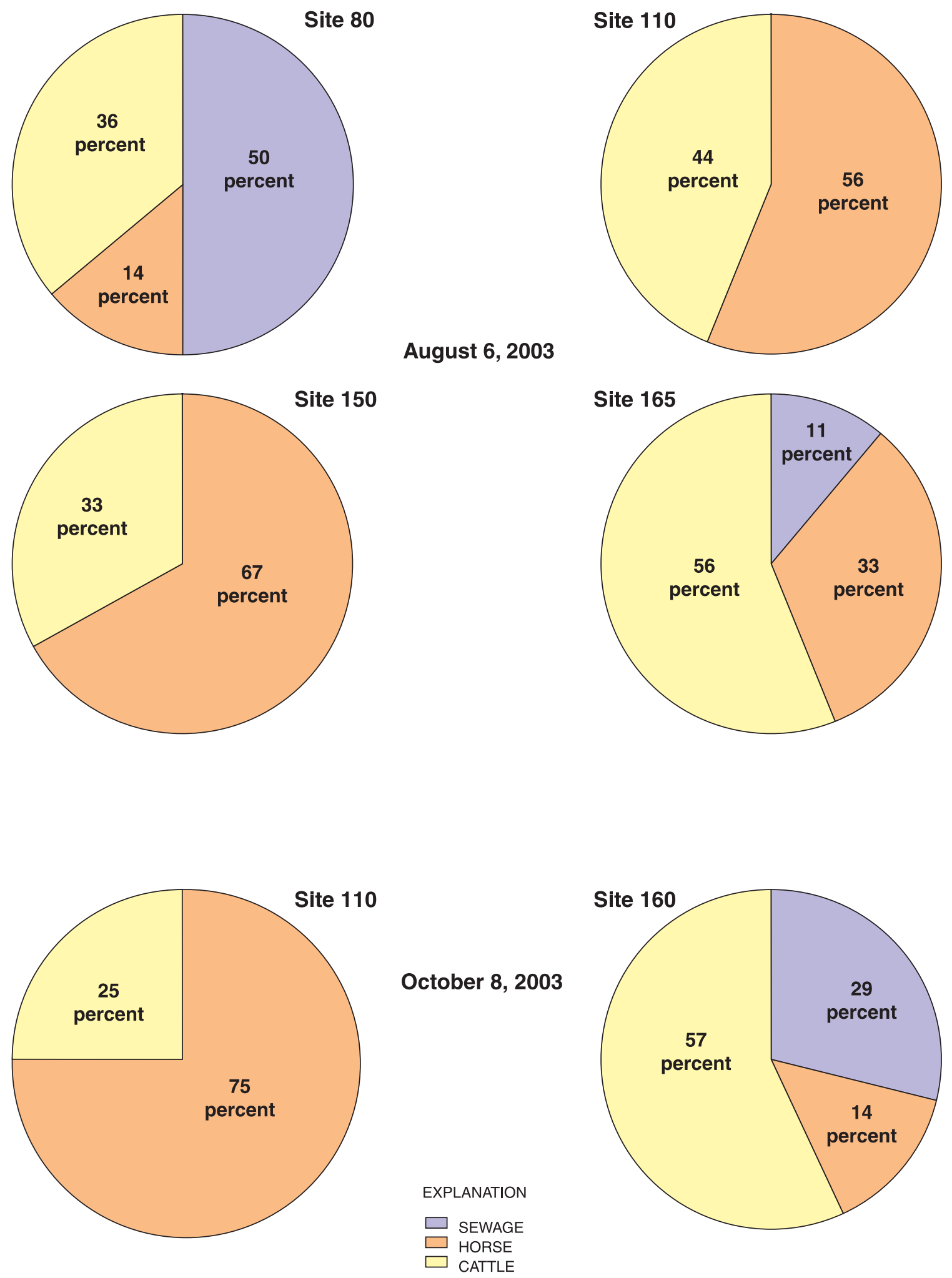

Figure 15. Percentage of Escherichia coli isolates in water-column samples assigned to various sources by repetitive polymerase chain reaction. 


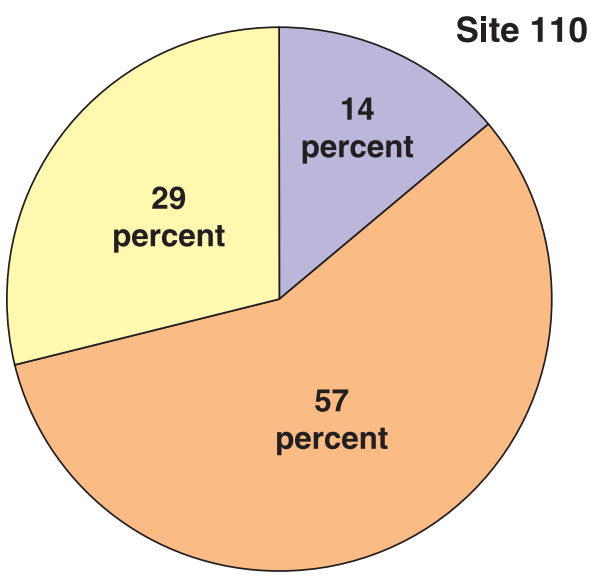

June 15, 2004

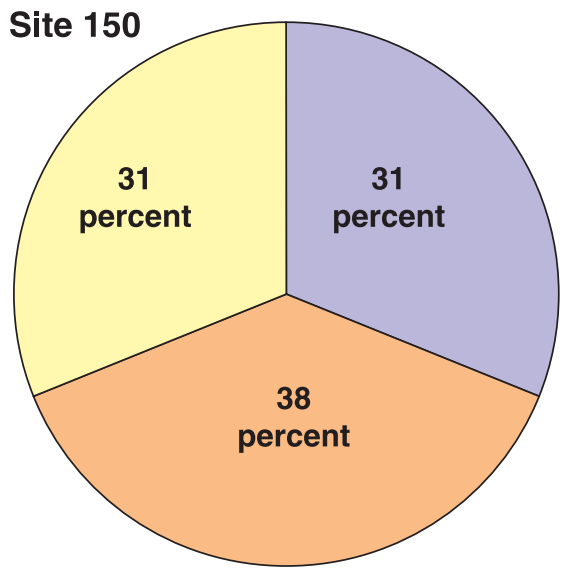

Site 160
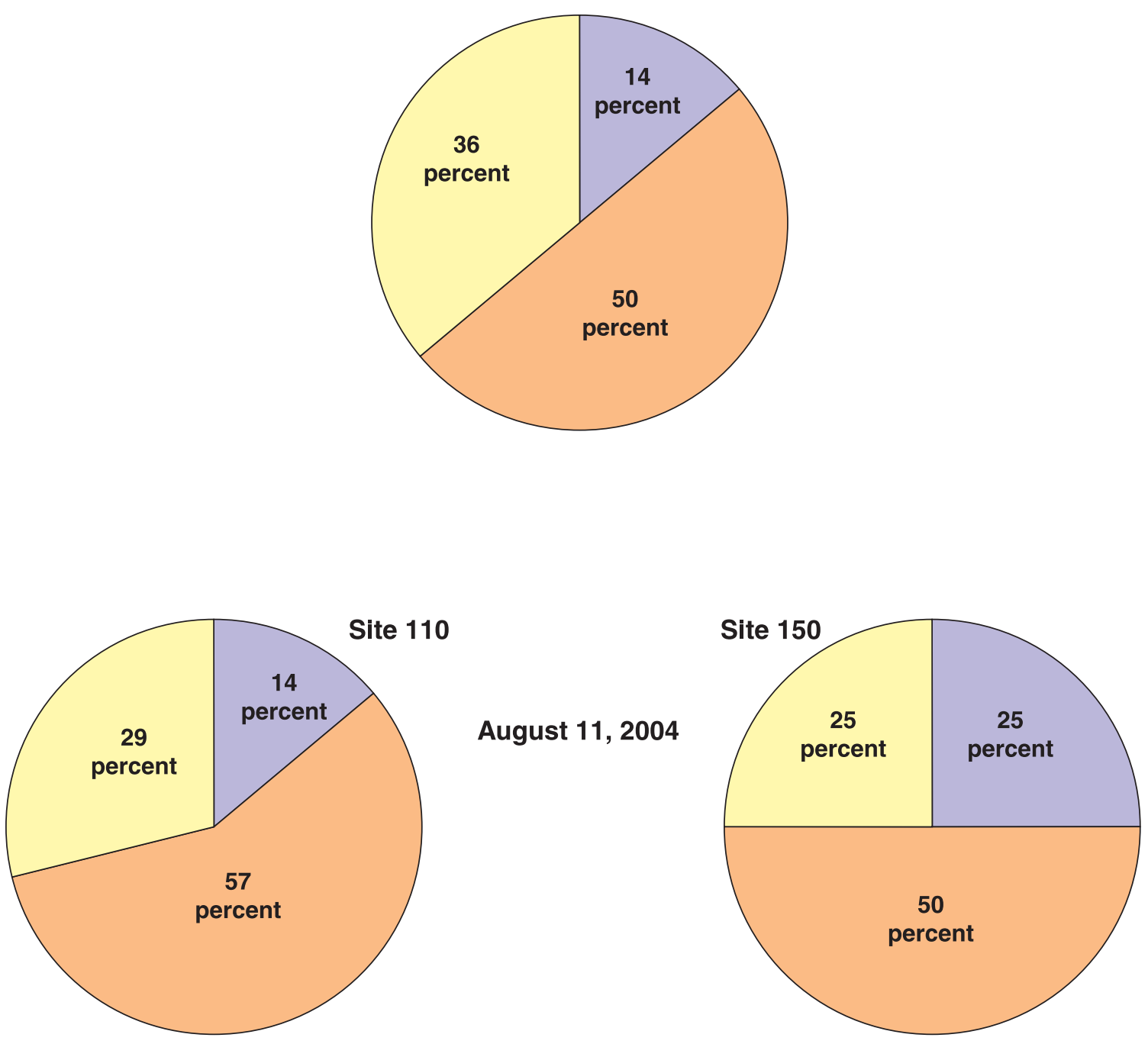

Figure 15. Percentage of Escherichia coli isolates in water-column samples assigned to various sources by repetitive polymerase chain reaction.-Continued 
fecal coliform density of $780 \mathrm{col} / 100 \mathrm{~mL}$ at site 80 on August 6, 2003, may have been affected by effluent from the Eminence Wastewater Treatment Plant (WWTP). The fecal coliform density was $7,300 \mathrm{col} / 100 \mathrm{~mL}$ in a sample collected on the same day from the Eminence WWTP.

Fecal coliform bacteria density at site 80 was significantly greater than fecal coliform bacteria densities at site 5 and Alley Spring (site 15). Shawnee Creek (site 160), the tributary sampled during Phase III, generally had larger fecal coliform densities than the main-stem sites. The Eminence WWTP also generally was not a contributor to the fecal coliform bacteria densities in the Jacks Fork. The exception was a sample collected on August 6, 2003, when the fecal coliform density was $7,300 \mathrm{col} / 100 \mathrm{~mL}$. The Eminence WWTP may have contributed to the large fecal coliform bacteria density observed on the same day downstream at site $80(780 \mathrm{col} / 100 \mathrm{~mL})$, an interpretation supported by microbial source tracking data indicating that sewage was the predominate source.

To compare the effects of intense trail-ride activity and large volumes of boaters and swimmers on fecal indicator bacteria densities, hourly sampling for fecal coliform and E. coli bacteria was done at site 110 on selected dates on weekends when no trail rides were taking place and on weekdays when trail rides occurred. During the weekend sampling, the number of canoes, kayaks, and tubes passing site 110 was recorded hourly. Likewise, during the weekday trail-ride sampling, the number of horses crossing at the site was recorded hourly. Generally, the fecal coliform bacteria densities tended to decrease or stay somewhat constant as the number of canoes, kayaks, and tubes passing site 110 increased. During the hourly sampling done on August 5, 2003, fecal coliform bacteria densities tended to increase throughout the day (with peaks of 720 and $1,200 \mathrm{col} / 100 \mathrm{~mL}$ in samples collected at 11:00 a.m. and 4:00 p.m.), even though the number of horses crossing the Jacks Fork decreased substantially in the afternoon. During the hourly sampling done on October 7, 2003, and August 10, 2004, the fecal coliform densities tended to increase as the number of horses crossing the river increased, and decrease with a decrease in the number of horses crossing the river.

Because bacteria can survive longer in streambed sediments than in water, a source of bacteria in the water column could be from resuspension of accumulated bacteria from streambed sediments. Streambed-sediment samples were collected at all Jacks Fork main-stem and tributary sites and analyzed for fecal coliform and E. coli bacteria. The only statistically significant differences between the distributions of fecal coliform bacteria densities in streambed sediments at seven Jacks Fork main-stem sites and Alley Spring were at sites 80 and 185, which had significantly larger fecal coliform bacteria densities than site 60 . However, the largest fecal coliform bacteria densities in the water column and streambed sediment generally occurred when trail rides occurred.

The relation of fecal coliform density in the water column to fecal coliform density in streambed sediment had a small positive correlation, with fecal coliform densities in streambed sediment accounting for only about 4 percent of the variation in the fecal coliform bacteria densities in the water column. The relation of fecal coliform density in streambed sediment to sediment particle size of less than 2,000 micrometers (sand, silt, and clay) had a positive correlation, with particle size of less than 2,000 micrometers accounting for about 19 percent of the variation in the fecal coliform bacteria densities in streambed sediments. This may indicate a hydromorphological effect, in that velocities that scour fine sediments also reduce deposition of fecal indicator bacteria.

It is apparent from the fecal coliform in streambed-sediment data that storage of fecal coliform bacteria in streambed sediments occurs, but the factors that affect the storage and release of these bacteria have not been determined. The presence of large densities of fecal bacteria in the water column during some trail rides cannot always be explained by storage and subsequent resuspension of fecal indicator bacteria in the Jacks Fork. This conclusion is supported by the observation that fecal coliform bacteria densities in the streambed sediments often were small when the densities were large in the water column. Conversely, the densities of fecal coliform bacteria often were small in the water column when the densities were large in the streambed sediment. The inconclusiveness of the results may be attributed, in part, to the study design. The measured bacteria densities are likely underestimated because of bacteria that fell out of suspension during the 10-hour settling time.

Isolates of E. coli obtained from water-column samples collected at five sites $(80,110,150,160$, and 165) were submitted for rep-PCR analysis to identify presumptive sources of fecal indicator bacteria in the Jacks Fork. A known-host source library, consisting of patterns from E. coli isolates obtained from sewage (215 isolates), cattle (229 isolates), and horse (215 isolates) feces samples collected within the Jacks Fork Basin from August 2002 through March 2005 was developed. A total of $501 \mathrm{E}$. coli isolates were analyzed; 70 isolates were assigned to sewage, 118 to cattle, 132 to horses, and 181 unknown. The rates of correct classification as determined by cross-validation were 85 percent for sewage, 88 percent for horses, and 94 percent for cattle.

The rep-PCR results for the individual samples that were collected at sites that had water column fecal coliform bacteria densities of 200 or greater $\mathrm{col} / 100 \mathrm{~mL}$ on the day of sample collection, as well as samples that had fecal coliform densities at the $75^{\text {th }}$ percentile level or greater, were examined in more detail. Rep-PCR samples collected on August 6, 2003, at sites 110 and 150 had a predominance of isolates attributed to horses; the predominant source at site 165 was cattle. Sewage was the predominant source in the sample collected at site 80 on the same day. The large percentage of isolates attributed to sewage in this sample probably is related to the release of effluent from the Eminence WWTP, which had a fecal coliform density of 7,300 col/100 mL on August 6, 2003. Rep-PCR analysis of samples collected at sites 110 and 160 on October 8, 2003, indicated that isolates identified as horse predominated at site 110 , whereas isolates identified as originating from cattle predominated at site 160. In samples collected on June 15, 2004, at sites 110, 150, and 160 and on August 11, 2004, at sites 110 and 150, 
isolates identified as originating from horses predominated. No cattle were observed grazing near the sites where cattle were identified as the predominant source. A source of the bacteria could be streambed sediments, which have been disturbed by trail-ride activity.

Both Phases I and II water-column sampling indicated that fecal coliform densities tended to increase to sometimes unacceptable levels during trail rides, but the exact causes for this increase and the sources of the fecal coliform bacteria were not positively identified. Phase III sampling was continued at 10 sites plus the Eminence WWTP since January 2001 with specific recreational activities (boating, swimming, tubing, and trail rides) being the primary focus of the sampling efforts. From June 2003 through October 2003 and from June 2004 through October 2004, streambed-sediment samples also were collected to examine the role that storage of fecal coliform in the streambed sediments and then subsequent resuspension may contribute to the overall fecal coliform bacteria problem. The microbial source tracking technique, rep-PCR analysis, was used to identify presumptive sources of fecal indicator bacteria in the Jacks Fork. Data collected during the Phase III study indicates the following:

- The largest fecal coliform bacteria densities in the water column and streambed sediment generally were detected in samples collected at the three main-stem sites (sites 80,110, and 150) with the most intense cross-country horseback trail-riding activity. Exceedences of the whole-body-contact recreation standard occurred at these sites during trail rides.

- Fecal indicator bacteria generally do not originate from the Eminence WWTP.

- Increasing numbers of canoes, kayaks, and tubes are not related to increasing fecal coliform bacteria densities in the water column at site 110 , but increasing numbers of horses crossing the river at site 110 are related to increasing densities.

- Rep-PCR analysis identified horses as the predominant possible source of fecal indicator bacteria in the Jacks Fork. Sewage accounted for the smallest contributor, followed by cattle. A source of the bacteria identified as originating from cattle could be streambed sediments, which have been disturbed by trail-ride activity.

- Recreational users (including boaters and swimmers) are not the primary source of fecal coliform bacteria in the Jacks Fork; rather, the presence of fecal coliform bacteria is associated with other animals, of which horses are the primary source. Increases in fecal coliform bacteria densities in the Jacks Fork are associated with cross-country horseback trail-riding events.

\section{References}

Aley, C., and Aley, T.J., 1987, Ground water study, Ozark National Scenic Riverways: Ozark Underground Laboratory, Protem, Missouri, v. I, 227 p.

Barks, J.H., 1978, Water quality in the Ozark National Scenic Riverways, Missouri: U.S. Geological Survey Water-Supply Paper 2048, $57 \mathrm{p}$.

Bromel, M., Saylor, G., Coles, G., Zimmerman, J., and Johnson, K., 1978, Bacteriological analyses of Lake Metigoshe water and sediments: Fargo, North Dakota State University, Agricultural Experiment Stations Bulletin 507, 14 p.

Carson, C.A., Shear, B.L., Ellersieck, M.R., and Asfaw, A., 2001, Identification of fecal Escherichia coli from humans and animals by ribotyping: Applied and Environmental Microbiology, v. 67, no. 4, p. 1,503-1,507.

Carson, C.A., Shear, B.L., Ellersieck, M.R., and Schnell, J.D., 2003, Comparison of ribotyping and repetitive extragenic palindromic-PCR for identification of fecal Escherichia coli from humans and animals: Applied and Environmental Microbiology, v. 69, no. 3, p. 1,836-1,839.

Davis, J.V., and Bell, R.W., 1998, Water-quality assessment of the Ozark Plateaus study unit, Arkansas, Kansas, Missouri, and Oklahoma-Nutrients, bacteria, organic carbon, and suspended sediment in surface water, 1993-95: U.S. Geological Survey Water-Resources Investigations Report 98-4164, $95 \mathrm{p}$.

Davis, J.V., and Richards, J.M., 2001, Assessment of microbiological contamination of the Jacks Fork within the Ozark National Scenic Riverways, Missouri-Phase I: U.S. Geological Survey Fact Sheet 026-01, 6 p.

Davis, J.V., and Richards, J.M., 2002, Assessment of microbiological contamination of the Jacks Fork within the Ozark National Scenic Riverways, Missouri-Phase II: U.S. Geological Survey Water-Resources Investigations Report 02-4209, 43 p.

Dombek, P.E., Johnson, L.K., Zimmerley, S.T., and Sadowsky, M.J., 2000, Use of repetitive DNA sequences and the PCR to differentiate Escherichia coli isolates from human and animal sources: Applied and Environmental Microbiology, v. 66 , no. 6, p. 2,572-2,577.

Doyle, J.D., Runnicliff, B., Kramer, R., Kuehl, R., and Brickler, S.K., 1992, Instability of fecal coliform populations in waters and bottom sediments at recreational beaches in Arizona: Water Research, v. 26, p. 979-988.

Dufour, A.P., 1977, Escherichia coli-The fecal coliform, in Hoadley, A., and Dutka, B.J., eds., Bacterial indicators/ health hazards associated with water, 1977: American Society for Testing and Materials, ASTM STP 635, p. 48-58.

Dugan, J.T., and Peckenpaugh, J.M., 1985, Effects of climate, vegetation, and soils on consumptive water use and groundwater recharge to the Central Midwest regional aquifer system, Mid-Continent United States: U.S. Geological Survey Water-Resources Investigations Report 85-4236, 77 p. 
Edwards, T.K., and Glysson, G.D., 1998, Field methods for measurement of fluvial sediment: U.S. Geological Survey Techniques of Water-Resources Investigations, book 3, chap. $\mathrm{C} 2,80 \mathrm{p}$.

Emrie, G.E., 1986, Fecal coliform as an indicator of water quality and recreational carrying capacity at Ozark National Scenic Riverways: Springfield, Southwest Missouri State University, unpublished M.S. thesis, $65 \mathrm{p}$.

Fenneman, N.M., 1938, Physiography of eastern United States: New York, McGraw-Hill Book Co., Inc., 689 p.

Fishman, M.J., ed., 1993, Methods of analysis by the U.S. Geological Survey National Water Quality Laboratory-Determination of inorganic and organic constituents in water and fluvial sediments: U.S. Geological Survey Open-File Report 93-125, $217 \mathrm{p}$.

Francy, D.S., and Darner, R.A., 1998, Factors affecting Escherichia coli concentrations at Lake Erie public bathing beaches: U.S. Geological Survey Water-Resources Investigations Report 98-4241, 41 p.

Grimes, D.J., 1980, Bacteriological water quality effects of hydraulically dredging contaminated upper Mississippi River bottom sediment: Applied and Environmental Microbiology, v. 39, no. 4, p. 782-789.

Guy, H.P., 1969, Laboratory theory and methods for sediment analysis: U.S. Geological Survey Techniques of WaterResources Investigations, book 5, chap. C1 [variously paged].

Hartel, P.G., Segars, W.I., Stern, N.J., Steiner, J., and Buchan, A., 1999, Ribotyping to determine the host origin of Escherichia coli isolates in different water samples, in Olsen, D.S., and Potyondy, J.P., eds., Wildland Hydrology, 1999: American Water Resources Association, TPS-99-3, p. 377-382.

Hartel, P.G., Summer, J.D., Hill, J.L., Collins, J.V., Entry, J.A., and Segars, W.I., 2002, Biogeographic variability of Escherichia coli ribotypes from Idaho and Georgia: Journal of Environmental Quality, v. 31, no. 4, p. 1,273-1,278.

Hauck, H.S., and Harris, T.E., 2006, Water resources data Missouri water year 2005: U.S. Geological Survey Water-Data Report MO-05-1, 724 p.

Hauck, H.S., and Nagel, C.D., 2000, Water resources data Missouri water year 1999: U.S. Geological Survey Water-Data Report MO-99-1, 390 p.

Hauck, H.S., and Nagel, C.D., 2001, Water resources data Missouri water year 2000: U.S. Geological Survey Water-Data Report MO-00-1, 430 p.

Hauck, H.S., and Nagel, C.D., 2002, Water resources data Missouri water year 2001: U.S. Geological Survey Water-Data Report MO-01-1, 504 p.

Hauck, H.S., and Nagel, C.D., 2003, Water resources data Missouri water year 2002: U.S. Geological Survey Water-Data Report MO-02-1, 548 p.

Hauck, H.S., and Nagel, C.D., 2004, Water resources data Missouri water year 2003: U.S. Geological Survey Water-Data Report MO-03-1, 430 p.
Hauck, H.S., and Nagel, C.D., 2005, Water resources data Missouri water year 2004: U.S. Geological Survey Water-Data Report MO-04-1, 430 p.

Helsel, D.R., and Hirsch, R.M., 1992, Statistical methods in water resources: Amsterdam, Netherlands, Elsevier, 522 p.

Imes, J.L., and Emmett, L.F., 1994, Geohydrology of the Ozark Plateaus Aquifer System in parts of Missouri, Arkansas, Oklahoma, and Kansas: U.S. Geological Survey Professional Paper 1414-D, 127 p.

Lehman, G.S., and Fogel, M.M., 1976, Investigation of bacteriological pollution of recreational waters in Arizona: Tucson, University of Arizona Department of Watershed Management and University of Arizona School of Renewable Natural Resources.

Marino, R.P., and Gannon, J.J., 1991, Survival of fecal coliforms and fecal streptococci in storm drain sediments: Water Research, v. 25, no. 9, p. 1,089-1,098.

McLellan, S.L., 2004, Genetic diversity of Escherichia coli isolated from urban rivers and beach water: Applied and Environmental Microbiology, v. 70, no. 8, p. 4,658-4,665.

Missouri Department of Natural Resources, 1998, Water quality investigation of the Jacks Fork River, Shannon and Texas Counties, May-November 1998: Jefferson City, Missouri, Division of Environmental Quality, Environmental Services Program, $133 \mathrm{p}$.

Missouri Department of Natural Resources, 2000, Missouri water quality standards-Chapter 7, Water quality: Jefferson City, Missouri, Clean Water Commission, 136 p.

Missouri Department of Natural Resources, 2004, Total Maximum Daily Loads (TMDLs) for Jacks Fork River, Shannon County, Missouri: Jefferson City, Missouri, Water Pollution Control Program, accessed September 2005, at URL http:// www.dnr.state.mo.us/wpscd/wpcp/tmdl/ jacks_fork_r_final_tmdl.pdf.

Missouri Spatial Data Information Service, 2001, Land use/land cover data: Columbia, Missouri, accessed July 2001, at URL http://msdis.missouri.edu/pub/lulc.

Myers, D.N., Koltun, G.F., and Francy, D.S., 1998, Effects of hydrologic, biological, and environmental processes on sources and concentrations of fecal bacteria in the Cuyahoga River, with implications for management of recreational waters in Summit and Cuyahoga Counties, Ohio: U.S. Geological Survey Water-Resources Investigations Report 98-4089, 45 p.

Myers, D.N., and Wilde, F.D., eds., November 2003, Biological indicators (3d ed.): U.S. Geological Survey Techniques of Water-Resources Investigations, book 9, chap. A7, accessed October 2005 at http://pubs.water.usgs.gov/twri9A7/.

National Oceanic and Atmospheric Administration, 2003, Climatologic data annual summary, Missouri: Asheville, North Carolina, National Climatic Data Center.

National Oceanic and Atmospheric Administration, 2004, Climatologic data annual summary, Missouri: Asheville, North Carolina, National Climatic Data Center.

Orndorff, R.C., Harrison, R.W., and Weary, D.J., 1999, Geologic map of the Eminence quadrangle, Missouri: U.S. Geo- 
logical Survey Miscellaneous Investigations Map I-2653, scale 1:24,000. Available online at http://pubs.usgs.gov/ imap/i-2653.

Parveen, S., Portier, K.M., Robinson, K., Edmiston, L., and Tamplin, M.L., 1999, Discriminant analysis of ribotype profiles of Escherichia coli for differentiating human and nonhuman sources of fecal pollution: Applied and Environmental Microbiology, v. 65, no. 7, p. 3,142-3,147.

Patton, C.J., and Truitt, E.P., 2000, Methods of analysis by the U.S. Geological Survey National Water Quality Laboratory-Determination of ammonium plus organic nitrogen by a Kjeldahl digestion method and an automated photometric finish that includes digest cleanup by gas diffusion: U.S. Geological Survey Open-File Report 00-170, 31 p.

Pommequy, M., Guillard, J.F., Dupray, E., Derrien, A., Le Guyader, F., and Cormier, M., 1992, Enteric bacteria survival factors: Water Science and Technology, v. 25, p. 93-103.

Roszak, D.B., and Colwell, R.R., 1987, Survival strategies of bacteria in the natural environment: Microbiological Reviews, v. 51, p. 365-379.

Sargeant, J.M., Hafer, D.J., Gillispie, J.R., Oberst, R.D., and Flood, S.J., 1999, Prevalence of Escherichia coli O157:H7 in white-tailed deer sharing rangeland with cattle: Journal of the American Veterinary Medicine Association, v. 215, no. 6, p. 792-794.

Schlottmann, J.L., Tanner, R., and Samadpour, M., 2000, Reconnaissance of hydrology, water quality, and sources of bacterial and nutrient contamination in the Ozark Plateaus aquifer system and Cave Springs Branch of Honey Creek, Delaware County, Oklahoma, March 1999-March 2000: U.S. Geological Survey Water-Resources Investigations Report 00-4210, 66 p.

Schumacher, J.G., 2001, Water quality in the Upper Shoal Creek Basin, Southwestern Missouri, 1999-2000: U.S. Geological Survey Water-Resources Investigations Report 01-4181, $60 \mathrm{p}$.

Schumacher, J.G., 2003, Survival, transport, and sources of fecal bacteria in streams and survival in land-applied poultry litter in the Upper Shoal Creek Basin, Southwestern Missouri, 2001-2002: U.S. Geological Survey Water-Resources Investigations Report 03-4243, 45 p.

Stoeckel, D.M., Mathes, M.V., Hyer, K.E., Hagedorn, C., Kator, H., Lukasik, J., O’Brien, T.L., Fenger, T.W., Samadpour, M., Strickler, K.M., and Wiggins, B.A., 2004, Comparison of seven protocols to identify fecal contamination sources using Escherichia coli: Environmental Science and Technology, v. 38, no. 22, p. 6,109-6,117.

Sullivan, A.E., Foster, D.I., Given, D., Einwalter, D.C., Graham, T., and Simpson, J., 1989, River use management plan-Ozark National Scenic Riverways: U.S. Department of the Interior, National Park Service, Denver Service Center, $46 \mathrm{p}$.

U.S. Department of Agriculture, 2002, Census of agriculture: Missouri State and county profiles: National Agriculture Statistics Service, accessed March 2006, at URL http:// www.nass.usda.gov/census/census02/profiles/mo/ index.html.

U.S. Environmental Protection Agency, 1985, Test methods for Escherichia coli and enterococci in water by the membrane filter procedure: U.S. Environmental Protection Agency, Cincinnati, Ohio, EPA 600/4-85-076, 24 p.

U.S. Environmental Protection Agency, 1986, Ambient water quality criteria for bacteria-1986: U.S. Environmental Protection Agency, Office of Water Regulations and Standards Division, Washington, D.C., EPA 440/5-84-002, 24 p.

University of Missouri, 2001, Population for Missouri counties, municipalities, and legislative districts 1990 and 2000: Office of Social and Economic Data Analysis, Missouri State Census Data Center Program, 10 p., accessed May 2001, at URL http://mcdc.missouri.edu/census2000/p194171.html.

Vandike, J.E., 1995, Surface water resources of Missouri-Missouri state water plan series, volume 1: Rolla, Missouri Department of Natural Resources, Geological Survey and Resource Assessment Division, Water Resources Report 45, $122 \mathrm{p}$.

Wilde, F.D., and Radtke, D.B., eds., 1998, National field manual for the collection of water-quality data-Field measurements: U.S. Geological Survey Techniques of WaterResources Investigations, book 9, chap. A6, 238 p.

Wilde, F.D., Radtke, D.B., Gibs, J., and Iwatsubo, R.T., eds., 1999a, National field manual for the collection of water-quality data-Collection of water samples: U.S. Geological Survey Techniques of Water-Resources Investigations, book 9, chap. A4, 103 p.

Wilde, F.D., Radtke, D.B., Gibs, J., and Iwatsubo, R.T., eds., 1999b, National field manual for the collection of waterquality data-Processing of water samples: U.S. Geological Survey Techniques of Water-Resources Investigations, book 9, chap. A5, 128 p. 